Universidad de Lima

Facultad de Comunicación

Carrera de Comunicación

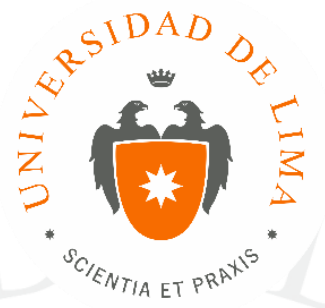

\title{
La construcción de memoria y la sentencia a Alberto Fujimori por los crímenes de La Cantuta en la prensa peruana
}

Trabajo de Investigación para optar la licenciatura en Comunicación

\author{
Sally Melanie Jabiel Córdova
}

Código 20100554

\section{Asesora}

Thelmy María del Carmen Mendoza Michilot

$$
\text { Lima - Perú }
$$

Agosto de 2016 


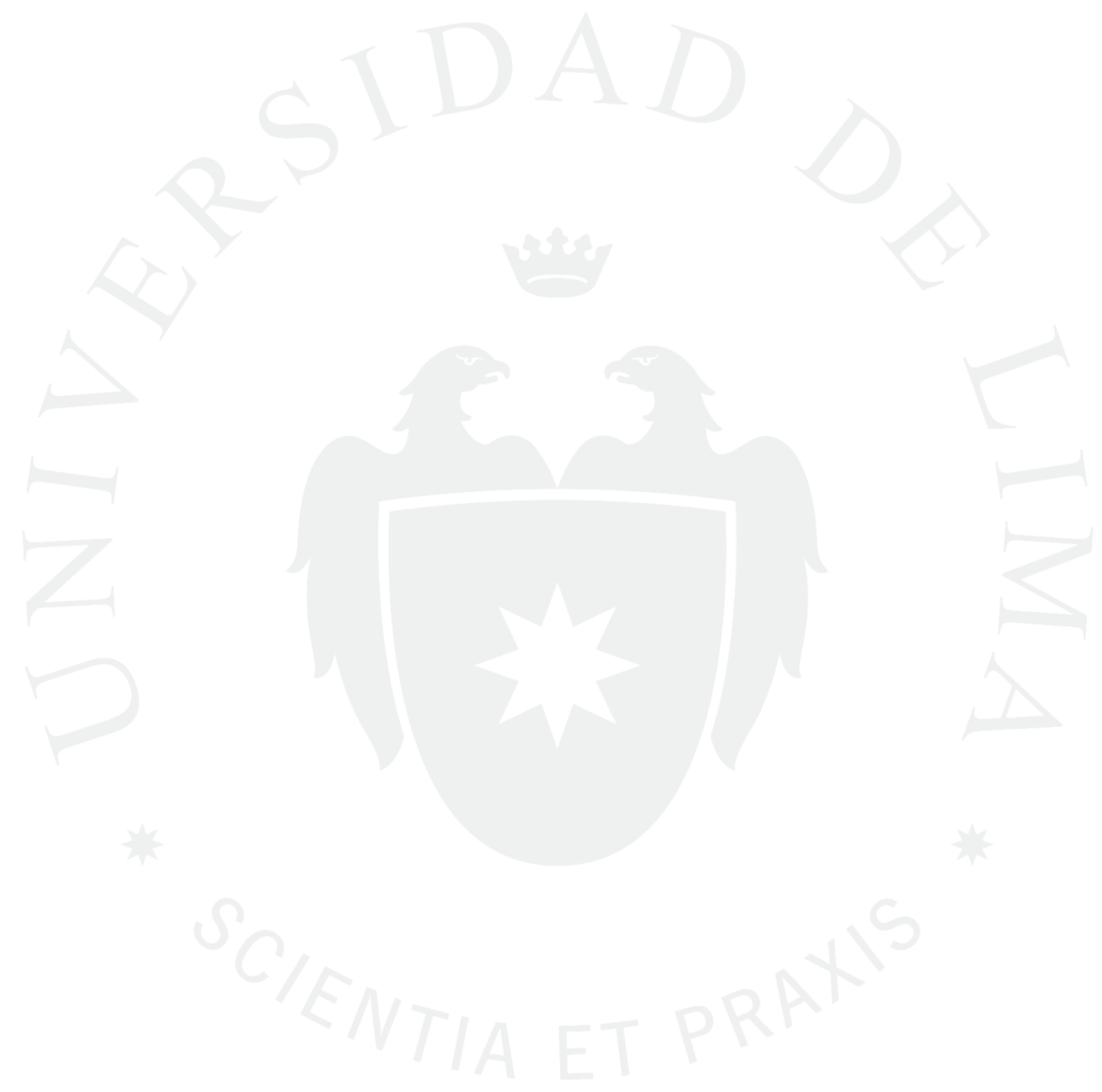


La construcción de memoria y la sentencia a Alberto Fujimori por los crímenes de La Cantuta en la prensa peruana 


\section{RESUMEN}

La sentencia a Alberto Fujimori por los crímenes de nueve estudiantes y un profesor de la Universidad de Educación Enrique Guzmán y Valle - La Cantuta no solo puso por primera vez en el banquillo de los acusados a un expresidente latinoamericano por delitos de lesa humanidad, sino que reconoció las memorias, en plural y en lucha, que disputan la representación del pasado de horror y violencia en Perú. A diferencia del fujimorato, cuando la mayoría de medios de comunicación se coludieron con este, en el 2009 los diarios más influyentes del país hicieron un amplio despliegue del proceso judicial. El presente artículo ofrece una mirada interpretativa a dicha cobertura y su contribución a la construcción de memoria. Analiza la calidad de las noticias publicadas, así como los juicios y atribuciones reflejados en los editoriales de El Comercio y La República. Recoge los testimonios de algunos familiares de las víctimas, de políticos, periodistas y miembros de la Comisión de la Verdad y Reconciliación (CVR), y contrasta 'ausencias' y 'presencias' en las narrativas de ambos diarios que revelan cómo, desde sus particulares líneas editoriales, contribuyeron a lo que Salomón Lerner Febres llama una 'memoria previa', una selección de acontecimientos recuperados y conservados que, si bien difundidos de manera fidedigna, estuvieron encaminados a una 'memoria de reconciliación' necesaria para dignificar a las víctimas, fortalecer la democracia y consolidar la paz en el país.

PALABRAS CLAVE: memoria, periodismo, justicia transicional, conflicto armado interno, La Cantuta, Alberto Fujimori 


\section{INTRODUCCIÓN}

Con uno de los juicios más eminentes de Latinoamérica, el 7 de abril del 2009 por primera vez un expresidente, elegido en democracia, fue condenado por su autoría mediata en delitos de lesa humanidad en su país. Tras más de 17 años de impunidad, la Corte Suprema del Perú aseveró la responsabilidad de Alberto Fujimori en las desapariciones forzadas y ejecuciones extrajudiciales de nueve estudiantes y un profesor de la Universidad Nacional de Educación Enrique Guzmán y Valle - La Cantuta. Ante esta sentencia a 25 años de pena privativa de la libertad, calificada como una lección histórica (Prado, 2014), los medios de comunicación realizaron un amplio despliegue noticioso, como un síntoma de lo podría ser una memoria más inclusiva y justa para las víctimas; y una suerte de conclusión al esfuerzo periodístico de quienes durante el régimen fujimorista develaron los crímenes perpetrados por grupos paramilitares y escuadrones de la muerte.

Cabe destacar que cuando se inició este proceso judicial, Perú ya había aprobado los informes de la Comisión de la Verdad y Reconciliación (CVR) que, en el caso La Cantuta, certificó cómo este cuestionado régimen negó a los familiares de las víctimas la información del destino de sus desaparecidos. También reconoció el aporte de los periodistas de la revista Sí en el esclarecimiento de los hechos a diferencia de un sector mayoritario de la prensa peruana que "sacrificó su independencia para servir a los intereses de un régimen corrupto que se preocupó de acallar cualquier denuncia sobre violaciones de los derechos humanos" (CVR, 2003, p. 489).

Algunas investigaciones han desentrañado las particularidades de la cobertura informativa realizada por los diarios nacionales tras la condena a Fujimori (Acevedo, 2012). El presente artículo plantea nuevas interrogantes y ofrece una mirada interpretativa sobre la contribución de la prensa peruana a la construcción de la memoria de un pasado doloroso y, a veces, desconocido por las nuevas generaciones, pero de ineludible análisis para avanzar hacia un futuro de reconciliación en el país.

Se debe recordar que la sentencia a Fujimori se inscribe en el proceso de justicia transicional que Naciones Unidas define como "la variedad de procesos y mecanismos asociados con los intentos de una sociedad por resolver los problemas derivados de un pasado de abusos a gran escala, a fin de que los responsables rindan cuentas de sus actos, servir a la justicia y lograr la reconciliación” (UN, 2004, p.6), vale 
decir, la situación posterior al abandono del Estado donde los derechos humanos se vulneraron y se dispone a investigar, juzgar y reparar; defendiendo el derecho a la verdad, no solo de las víctimas, sino de la sociedad, para comprender lo sucedido y garantizar la no repetición (FLIP, 2009).

El periodismo asume la labor de investigar las condiciones que rodearon los abusos cometidos y el cumplimiento de los ideales de transición que son verdad, justicia y reparación (FLIP, 2009). La trascendencia de esta investigación recae, así, en que el periodismo "no solo puede contribuir en grande a develar la verdad, sino también a contextualizar y a hacer seguimiento a los hechos" (FIP, 2008, p. 5), esto es, tiene el doble desafío de avanzar en la búsqueda de la verdad y de "garantizar rigor y calidad en sus informaciones para que en el futuro sean valorados como fuente legítima y objetiva para cualquier esfuerzo de construir la historia, la identidad y la memoria de una nación que superó la violencia" (FIP, 2008, p. 39). Como afirma Marialva Barbosa, "la memoria es parte del trabajo periodístico porque, a través de ella, el profesional selecciona constantemente elementos para construir la historia del pasado y fijar lo que debe ser recordado en el futuro" (2005, p. 108).

En ese marco, la memoria es una selección donde algunos rasgos del suceso serán conservados, otros inmediata o progresivamente marginados, y luego olvidados" (Todorov, 2000, p. 16), un proceso que no ocurre en individuos aislados (Jelin, 2002). Los hechos del pasado se ubican en contextos sociales y específicos, se organizan mediante narrativas que le otorgan sentido "y se posicionan como memorias cuando son capaces de articular nuestras experiencias presentes en marcos de sentido con capacidad persuasiva y eficacia social” (Barrantes y Peña, 2006, p.16).

La memoria, por tanto, es un "espacio de lucha política" (Jelin, 2003, p. 31), "el resultado de un complejo juego de transacciones entre fuerzas sociales contrapuestas que pretenden dictar el contenido de aquello que debe ser olvidado" (Manrique, 2003, p. 422). En países con un pasado de represión, como Argentina y Chile, se identifican, al menos, tres luchas políticas: de búsqueda de justicia para las víctimas, de política de olvido bajo el pretexto de resguardar la democracia, y de enaltecimiento de ese pasado dictatorial (Jelin, 2003). Para el presidente de la CVR, Salomón Lerner Febres, estas contrarían la "memoria ética" que no debe ser fabricada "como instrumento político, si no, por el contrario, por un recordar comunitario, fiel a los hechos y respetuoso de las experiencias de esos hechos" (2004, p. 348), imprescindible en una sociedad como la 
peruana donde las "batallas de la memoria" se entablan entre una memoria de salvación y una memoria de reconciliación.

El antropólogo Carlos Ivan Degregori (2013) nomina la memoria de salvación como aquella que, promovida por el régimen fujimorista, conjuga a Fujimori, su asesor Vladimiro Montesinos y las fuerzas del orden como los únicos salvadores del país, en tanto las violaciones a los derechos humanos que cometieron fueron el costo necesario para erradicar la violencia terrorista. Esta memoria, además, de vincularse con la "memoria manipulada" de Paul Ricouer (2004) que sustenta la ideología de un poder cuyo relato trastoca la memoria hacia "una historia oficial" de "memoria impuesta"; corresponde a una visión del pasado donde prevalece el interés de mantener el orden y la seguridad pese a que se vulneran los valores democráticos y la justicia (Barrantes y Peña, 2006). En oposición, la memoria de reconciliación nace del cuestionamiento a tal "memoria oficial" y se entiende a partir de su similitud con la "memoria ejemplar" de Tzvetan Todorov (2000, p. 49) que recurre al aprendizaje de la experiencia pasada para actuar con justicia en el futuro. En Perú esta memoria nació de los organismos de derechos humanos, el periodismo de oposición y las memorias silenciadas de los familiares de las víctimas con una visión del pasado que busca justicia sobre los crímenes, reconocimiento a las víctimas y garantías de no repetición (Degregori, 2004).

En consecuencia, el periodismo incide como catalizador de la conciencia social para enfrentar la verdad y construir una cultura de paz que desacredite "conductas sociales que glorifican, idealizan o naturalizan el uso de la fuerza y la violencia, o que ensalzan el desprecio y el desinterés por los demás" (Fisas, 2006, p. 360) y, además, como crítico ante las declaraciones de los victimarios (FLIP, 2009) quienes, aunque “son el eje del proceso judicial (...), no demandan más atención que las víctimas en medio de una situación de esclarecimiento de la verdad y de reconstrucción de la memoria" (FIP, 2008, p. 38).

Este artículo se inscribe en dicha perspectiva y aborda preguntas claves como: ¿Cuál es el despliegue periodístico que merece un proceso de justicia transicional como la sentencia a Fujimori? ¿Con qué voces se narra el posconflicto en los diarios más influyentes del país? ¿Cómo se involucran y articulan a las memorias de las víctimas y victimarios? ¿Cómo y qué memoria se refuerza en la prensa peruana?

Para responder a tales interrogantes, la investigación se sostiene en la propuesta de Silvia Pellegrini (2006) en la cual la calidad informativa es medible bajo el concepto del Valor Agregado Periodístico (VAP), es decir, la capacidad del periodista 
para procesar y brindar información al público sin distorsionar la realidad con la selección de lo que es noticia y las fuentes involucradas, y finalmente con la elaboración del mensaje que se difundirá con contexto, profundización y enfoques adecuados. A esta medición se suma el valor de la fotografía como verdadero documento social (Del Valle, 2002), así como el de los juicios contenidos en los editoriales de la prensa que ponderan que está bien y mal, convirtiendo a los diarios en una especie de guardianes de la conciencia pública (Hernando, 2001). Del mismo modo, este trabajo se valida con los aportes de investigaciones como la del Proyecto Nariño (2004) que asocia calidad periodística a la pluralidad, la precisión y la diversidad; y la de Teresa Teramo que realza la ventaja de estudios similares ya que "la información de calidad contribuye al desarrollo social y a la democracia” (2006, p.58), sobre todo luego de fenómenos de violencia como el peruano donde, además, según Carlos Oviedo, se debe "escrutar el quehacer periodístico por dentro; ver sus esfuerzos, así como sus ligerezas y yerros en la cobertura y en el enfoque de los hechos" (1989, p.11).

Una reflexión crítica sobre la labor de los diarios en los procesos de justicia transicional es sin duda indispensable. "Los periódicos de una nación juegan un papel importante en la formación de la conciencia de sus ciudadanos" (Sorensen, 2015, p.129) y en Perú, un país que asume el posconflicto en miras de garantizar la no repetición, han de ser "emprendedores de la memoria" (Jelin, 2002, p.50) en tanto promuevan el reconocimiento y la dignificación de quienes ya no están.

Con los aprendizajes de esta investigación, se procura aportar al trabajo realizado en países como Colombia, Argentina y Chile donde periodistas y comunicadores han articulado manuales con reglas puntuales para cubrir acontecimientos de justicia transicional. Ello está pendiente aún en Perú, aunque es claro que la responsabilidad de los profesionales del periodismo es desempeñarse como verdaderos agentes de memoria, que reconozcan la pluralidad de memorias del conflicto, sensibilicen sobre los efectos de la violencia y direccionen a la sociedad hacia un futuro que rechace cualquier tentativa política por socavar la democracia, los derechos humanos y la paz. 


\section{METODOLOGÍA}

Esta investigación se desarrolló mediante una metodología mixta, con énfasis en lo cualitativo. Este método implica la recolección y el análisis de datos cuantitativos y cualitativos que permiten un mayor entendimiento de lo estudiado. En este sentido, la investigación cuantitativa brinda un punto de vista de conteo y facilita la comparación de resultados, mientras que la cualitativa, que en este caso se traduce en el análisis de contenidos, otorga la posibilidad de una profunda interpretación y contextualización de los datos. (Hernández, Férnandez, y Baptista, 2010).

Bajo esta perspectiva, el objeto de estudio fueron las publicaciones periodísticas de los diarios más influyentes del país, es decir, El Comercio y La República durante la cobertura de la sentencia a Alberto Fujimori por el caso La Cantuta, evento que "se recuerda más que Barrios Altos, a pesar de que allí murieron quince personas, incluyendo un niño de 8 años, porque se fue elaborando una historia, un discurso a partir de la investigación de la revista S厃̂’ (Degregori, 2013, p. 222). Se seleccionó a El Comercio, reconocido como decano de la prensa peruana, con un discurso liberal, asociado a la derecha nacional (Cosme, Jaime, Merino, y Rosales, 2007); y a La República, con una agenda esencialmente política y de defensa a los derechos humanos (Mendoza, 2013).

Como universo se consideraron los textos periodísticos de ambos diarios correspondientes a 14 días distribuidos en tres momentos claves de la sentencia judicial: la víspera de su emisión (del 4 al 6 de abril de 2009), su lectura (del 7 al 14 de abril de 2009) y su ratificación (del 2 al 4 de enero de 2010).

Al ser una investigación enfocada en el mensaje, se identificó y evaluó la calidad informativa de una muestra compuesta por 22 notas informativas y 16 reportajes, seleccionados mediante un muestreo no probabilístico basado en "toda información periodística que contiene: titular + cuerpo informativo + recursos visuales" (Proyecto Nariño, 2004, p. 77). De acuerdo al estudio de Pellegrini (2006), se analizó la muestra a través de los indicadores que dan cuenta del nivel de acceso a las fuentes y de la equidad informativa. El primer acceso se midió mediante el número y la naturaleza o tipo de las fuentes de la noticia. El segundo se evaluó por el contexto y las causas que originaron los hechos y se complementó, a su vez, con el aporte del trabajo de Teramo (2006) sobre contextualización y adjetivación (Anexo 5). 
Consideradas como "hechos comunicacionales" (Paz, 2002, p. 61), se escogieron las fotografías de las portadas de ambos medios para el día siguiente de la sentencia, por tratarse de la fecha más significativa. Tales imágenes fueron estudiadas bajo los criterios de la presencia o ausencia de los actores del caso en cuestión, con énfasis en las víctimas.

En cuanto a los 12 editoriales evaluados, se detalló la incidencia de juicios y atribuciones que ambos periódicos generaron respecto a Fujimori y sus seguidores, a los familiares de las víctimas, al juicio y a la sentencia según la función de formulación de juicios descrita por Natividad Abril (1999) quien, además, apunta a otras funciones del editorial como son explicar los hechos, dar antecedente y predecir el futuro (Anexo 6).

En lo cuantitativo, se evaluó el despliegue noticioso a partir de la metodología de Oviedo (1989). Se definió la presencia del caso en los tres momentos claves descritos en ambos medios de acuerdo con la cantidad de portadas donde figura el tema, así como el lugar otorgado en estas, y de la cantidad de textos publicados de acuerdo a su género periodístico.

Por último, para develar la construcción de memoria en las narraciones de la prensa limeña se emplearon los resultados del análisis de contenido en cuanto al despliegue que se le dio al caso, vale decir, la relevancia mediática que significó y su influencia en la agenda de los medios; la presencia y ausencia de determinados actores del conflicto como fuentes y en fotografías y, además, la adjetivación, los juicios y las atribuciones que merecieron en los relatos de los medios, ya que la memoria se compone de "agentes activos que recuerdan, y a menudo intentan transmitir y aun imponer sentidos del pasado a otros" (Jelin, 2002, p.33); la representación de los actores en la prensa nos infieren la manifestación de una de las memorias que hoy se disputan en el país.

Adicionalmente, se realizaron entrevistas en profundidad a periodistas que cubrieron la sentencia en ambos medios, como Mario Mejía de El Comercio y Ángel Páez de La República. Asimismo, se dialogó con uno de los familiares más representativos de las víctimas de La Cantuta - Gisela Ortiz, hermana de Enrique Ortiz, uno de los estudiantes desaparecidos-, y con una reconocida vocera del fujimorismo, la excongresista Martha Chávez. Igualmente, se consideró a un actor vinculado al estudio de derechos humanos y conflicto armado en Perú como el presidente de la Comisión de la Verdad y Reconciliación (CVR), Salomón Lerner Febres. Los hallazgos 
de análisis se vincularon y contrastaron con las declaraciones recogidas para determinar qué memoria reforzó la prensa más influyente del país. 


\section{RESULTADOS}

\section{Despliegue noticioso}

El conteo de las publicaciones del 4 de abril de 2009 al 5 de enero de 2010 proyectó un total de 160 textos periodísticos sobre la sentencia a Alberto Fujimori por los crímenes de La Cantuta en los diarios El Comercio y La República (Anexo 3 y 4). De esta cifra, la mayoría aparecieron en La República (114 textos).

El momento de mayor cobertura en ambos periódicos fue el día de la lectura de la sentencia y los días subsiguientes, con un total de 106 publicaciones. Se estima que la brecha entre La República y El Comercio se acrecienta en este período, si se considera que el primero es autor del $70 \%$ de los textos (Figura 1).

FIGURA 1. Resumen total de publicaciones por períodos

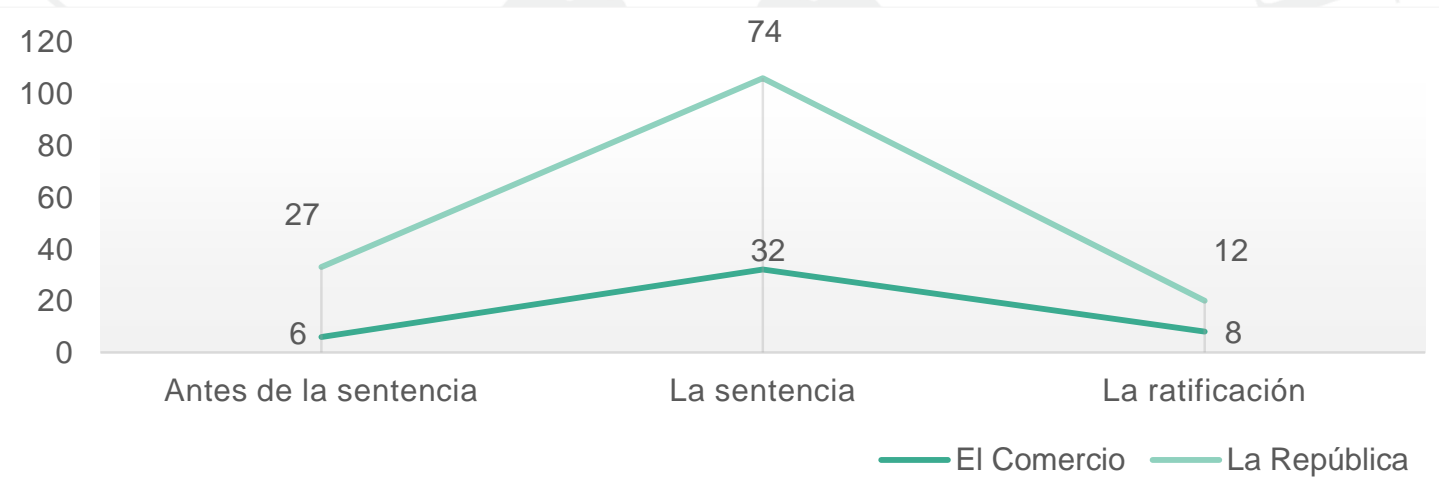

Fuente: Elaboración propia

Cabe destacar que, en los días previos a la emisión del veredicto judicial, La República hizo un seguimiento continuo. Publicó más de 27 textos a diferencia de El Comercio que solo hizo 6 publicaciones, en clara evidencia de uno de los pilares de su línea editorial que, desde la dirección de Gustavo Mohme Llona, ha sido y continúa siendo la defensa de los derechos humanos, el rechazo al gobierno fujimorista y la denuncia permanente de las desapariciones forzadas perpetradas a través de agentes del Estado. Esta diferencia cuantitativa en la cobertura se reduce durante la ratificación del fallo, recién al año siguiente, aunque mantiene siempre diferencias reveladoras ante $E l$ Comercio.

En cuanto al total de portadas que se otorgaron a los tres momentos de este análisis, se halló un total de 19 en ambos diarios (Figura 2) (Anexos 1 y 2). Esto es trascendental pues los medios al establecer agendas "sugieren puntos de partida 
apropiados para la discusión y el debate, al mismo tiempo que definen cuáles asuntos son importantes y cuáles son permitidos discutir" (Sorensen, 2015, p. 20) en público. Se desprende que este fallo judicial, como se expondrá más adelante, sí representó para $E l$ Comercio y La República un asunto de debate social.

FIGURA 2. Resumen total de portadas

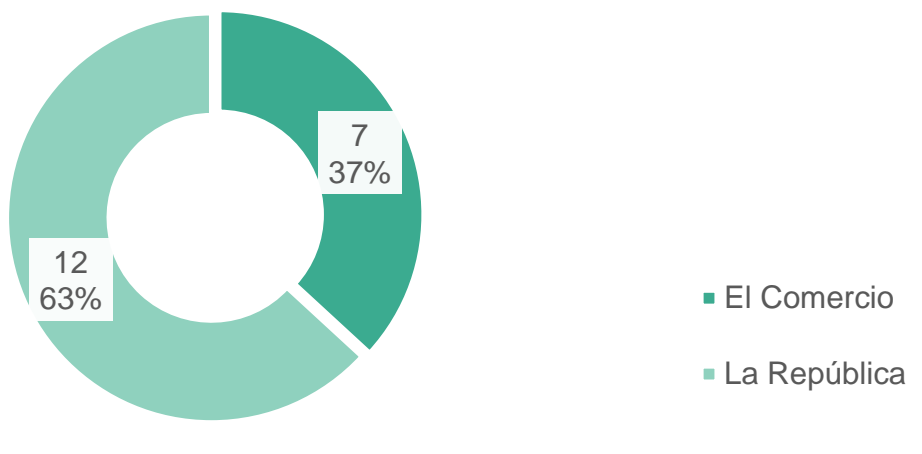

Fuente: Elaboración propia

No obstante, La República colocó el tema en su primera página no solo más veces que El Comercio, sino que lo posicionó como la noticia principal del día en cada fecha de su publicación. Como señala Karin Acevedo, para este diario fue tan relevante la sentencia como el trabajo de la justicia peruana a través de la sala del juez César San Martín (2012); un ejemplo es la portada titulada "El mundo los llena de elogios" (09/04/2009) que circuló a los dos días de la lectura.

Los días previos a la lectura de la condena a Fujimori, como se ha señalado, $L a$ República mantuvo la mayor cobertura. En este período, el tema fue tres veces el titular principal de las portadas: "7 de abril día de la sentencia" (04/04/2009), "Intenso debate" (05/04/2009), y "Perdió juicio ciudadano" (06/04/2009). El Comercio también tuvo el tema en dos oportunidades en la primera página, pero en titulares secundarios a manera de llamadas: "Ante la perorata de Fujimori, tribunal dice que fallo será jurídico" (04/04/2009) y "Proceso judicial cumplió todas las garantías" (06/04/2009). Esta diferencia apuntaría a que para estos dos diarios la relevancia y valorización atribuida al caso fue diferente, aunque ambos sostuvieron un monitoreo constante de la evolución del juicio.

El día de la lectura de la sentencia y los días subsiguientes hubo mayor exposición del tema (Figura 3). El Comercio lo colocó en tres 3 portadas, en dos de las cuales mereció titulares principales: "Que se haga justicia" (07/04/2009) y "Probado: secuestró y asesinó con alevosía" (08/04/2009). La República publicó 5 portadas, de las 
cuales la del día siguiente de la sentencia tuvo un formato especial con 3 titulares: "No eran terroristas", "Culpable de crímenes de lesa humanidad" y "25 años de cárcel" (08/04/2009).

FIGURA 3. Portadas al día de la sentencia

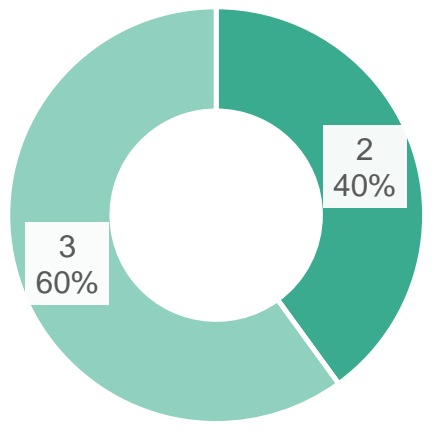

- El Comercio

- La República

Fuente: Elaboración propia

En ocasión de la ratificación de la sentencia (Figura 4), la cobertura disminuyó, aunque el caso siguió ganando portadas: La República le dedicó 5 y El Comercio 3. Sin embargo, se debe destacar que La República dio la noticia antes, el 2 de enero del 2010, mientras que El Comercio lo hizo dos días después.

FIGURA 4. Portadas a la ratificación de la sentencia

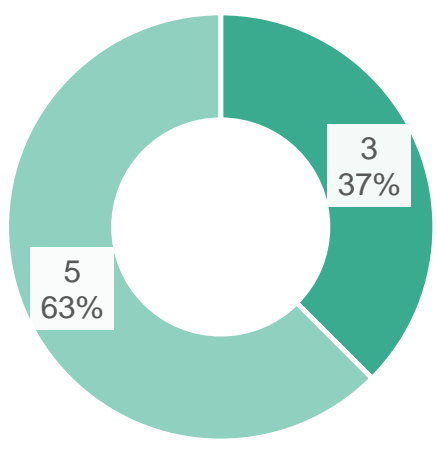

- El Comercio

- La República

Fuente: Elaboración propia

\section{Géneros periodísticos}

El género periodístico predominante para narrar la sentencia a Fujimori tanto en $E l$ Comercio como en La República fue la nota informativa (Figura 5) (Anexo 3 y 4): salieron 67 notas (40\% del total de textos publicados). Le siguió la columna de opinión con un total de 43 publicaciones (33\%). 
FIGURA 5. Resumen total de géneros periodísticos

ఐEl Comercio $\square$ La República

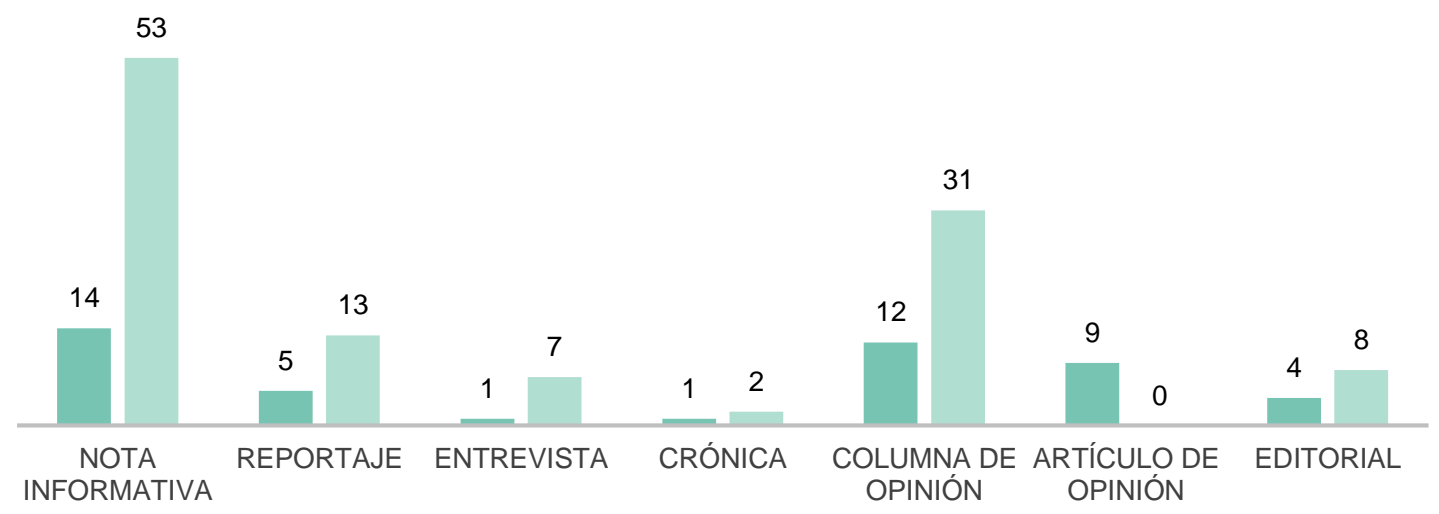

Fuente: Elaboración propia

La cobertura señala además que La República publicó más reportajes, entrevistas, crónicas y editoriales que El Comercio. Empero, en general, hubo poca profundización en la noticia, toda vez que no se dio espacio a los géneros más interpretativos que permitieran enmarcar o enfocar los acontecimientos. Esta carencia se cubrió con columnas de opinión que permiten presentar juicios de valor sin anonimato sobre los hechos más allá de la mera información (El País, 2014).

Se publicaron 13 reportajes en La República, pero mucho menos crónicas, un género que contextualiza y evalúa (El País, 2014). Ello pudo ocurrir por la extendida tendencia en los diarios de economizar espacio o dar a conocer los hechos de manera directa e inmediata. Como se sabe, la crónica demanda una extensión mayor (Grijelmo, 2006) y más tiempo de producción.

Desde el punto de vista cualitativo, cabe resaltar que las columnas y artículos de opinión de El Comercio apuntaron al pluralismo. Contrariamente a otras lecturas, que indican que la tendencia política de sus columnistas es prioritariamente de derecha (Acevedo, 2012), se observó que este caso hubo la predisposición de difundir otras voces, incluso con posturas contrapuestas respecto a la sentencia a Fujimori, como lo muestran las columnas de Henry Pease ("El autócrata es culpable") y Martha Chávez (“ ¡Oh, democracia, cuantos crímenes se cometen en tu nombre!”). Por su parte, $L a$ República publicó colaboraciones coincidentes con su línea editorial, entre las cuales puede mencionarse las de Mirko Lauer, Augusto Álvarez Rodrich y Jorge Bruce.

Si se analizan las publicaciones de acuerdo con los momentos vividos durante el proceso se confirma que, antes de la lectura de la sentencia, la mayor cobertura 
estuvo en manos de La República, gracias a las notas informativas y columnas de opinión que difundió (Figura 6). Mayor cobertura y, sobre todo, una continua vigilancia sobre el esperado veredicto.

FIGURA 6. Géneros periodísticos antes del día de la lectura de la sentencia El Comercio $\square$ La República

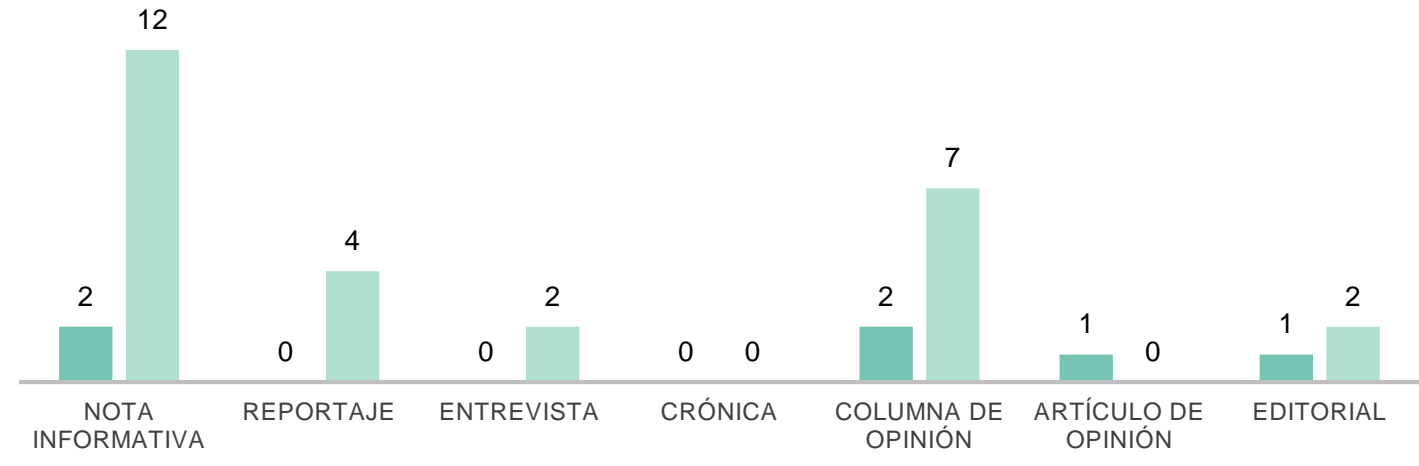

Fuente: Elaboración propia

El día de la lectura de la sentencia y los días subsiguientes el despliegue fue mayor en El Comercio, sobre todo en materia de reportajes y artículos de opinión (Figura 7).

FIGURA 7. Géneros periodísticos en la lectura de la sentencia El Comercio $\square$ La República

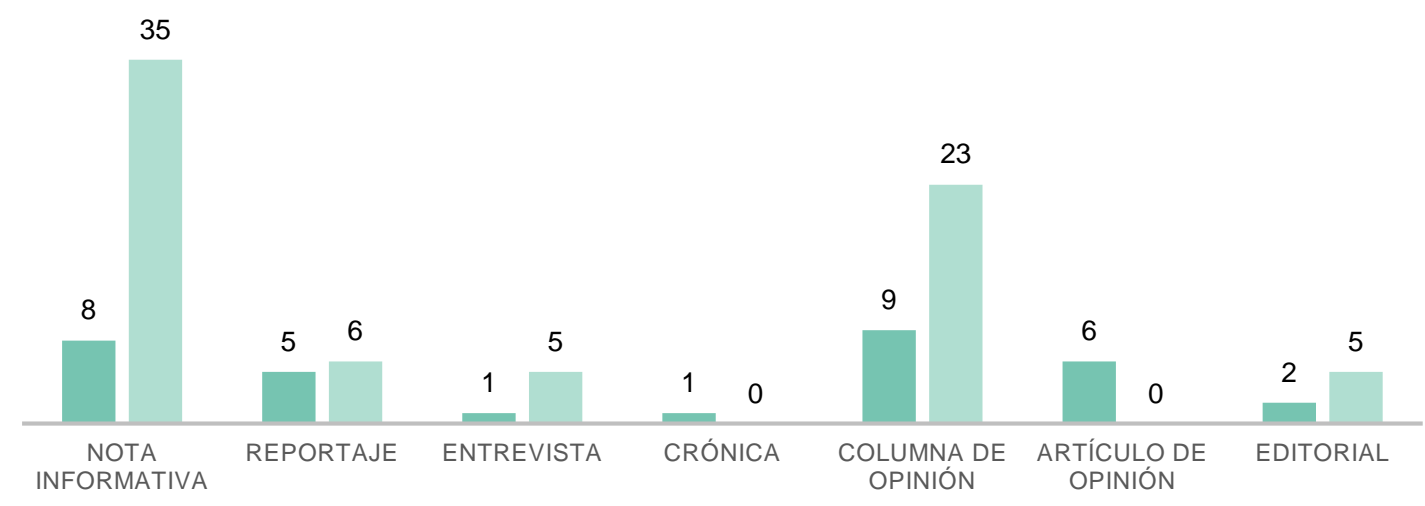

Fuente: Elaboración propia

La ratificación de la sentencia, sin embargo, no mereció la misma atención de los periódicos y, en especial, de El Comercio (Figura 8). 
FIGURA 8. Géneros periodísticos en la ratificación de la sentencia

-El Comercio $\quad$ La República

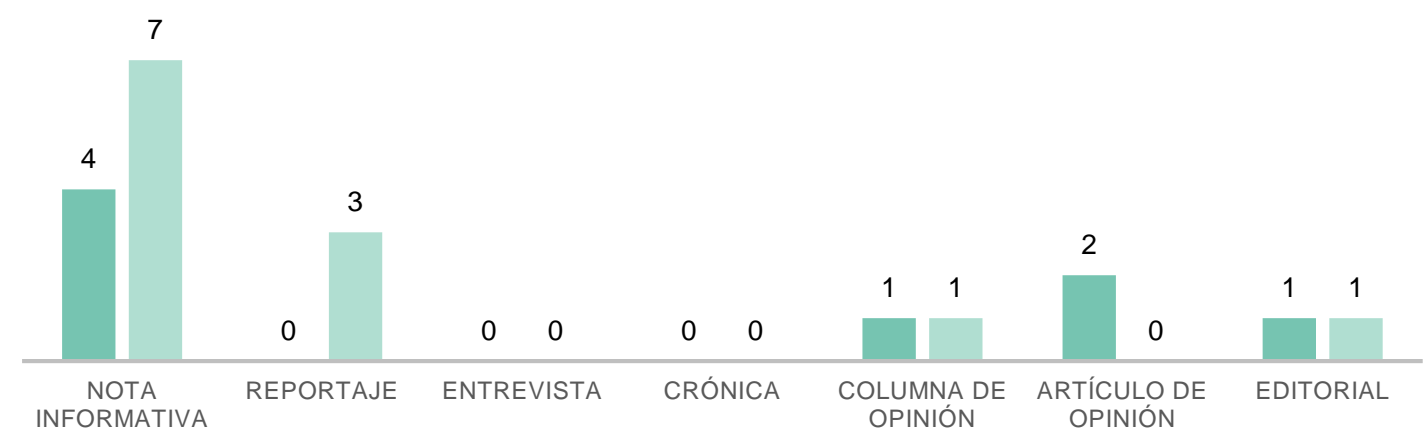

Fuente: Elaboración propia

\section{Calidad informativa}

\subsection{Fuentes}

En la cobertura noticiosa, La República empleó gran cantidad de fuentes en notas informativas y reportajes, que en algunos casos llegaron a nueve. Las principales fuentes consultadas fueron los familiares de las víctimas de La Cantuta, entre quienes sobresalen Raida Cóndor y Gisela Ortiz; voceros de organizaciones defensoras de las víctimas y de derechos humanos como Amnistía Internacional y APRODEH; juristas, ex procuradores y políticos, como Yehude Simon, Lourdes Flores, Yohny Lescano, Alejandro Toledo y Alan García. En menor medida, se recogió el punto de vista de la defensa de Fujimori o de sus partidarios, como Alejandro Aguinaga y Carlos Raffo.

Por otro lado, en El Comercio se constató el número de fuentes fue de hasta siete por nota. En este medio no se consideró a los familiares de las víctimas, pero sí se recogió el pronunciamiento de sus abogados, como Carlos Rivera. En mayor medida, se entrevistó a los partidarios de Fujimori, así como a magistrados, procuradores y fiscales.

\subsection{Adjetivación}

Alberto Fujimori aparece en La República como "ex presidente", "ex mandatario", "acusado", "procesado" o "líder fujimorista", pero también se le denomina "ex dictador", "caudillo" e incluso "sátrapa". Antes de la lectura de la sentencia esta adjetivación es más frecuente. Los seguidores de Fujimori son, utilizando el argot 
militar, sus "soldados", "huestes", miembros del "batallón" o "fuerzas de choque" fujimoristas. En contraste, los familiares de las víctimas de La Cantuta son personas sumidas en el sufrimiento, la pena, el dolor y la búsqueda de justicia.

En El Comercio, Fujimori es el "ex presidente", el "extraditado", el “procesado" y el "acusado de delitos de lesa humanidad". No se usa el adjetivo de “dictador”. Respecto a los fujimoristas, les atribuyó un accionar violento durante el proceso, protagonistas de "empujones", "puñetes" y "patadas", con lo cual coincidió con La República que también los calificó de "bulliciosos" y "beligerantes". A los familiares de las víctimas se les destaca por el festejo, la celebración y los abrazos que predominan tras la lectura de la sentencia.

En los días previos de la emisión de la sentencia y en el día mismo de su lectura ambos diarios se refirieron al juicio como "imparcial", "célebre" e "histórico" y a la sentencia como "contundente" y "drástica", es decir, para ambos la condena al expresidente Fujimori no solo fue histórica, sino totalmente justa por los abusos a los derechos humanos cometidos. Cuando el Poder Judicial ratificó la sentencia, La República y El Comercio coincidieron en que se trató de un veredicto "inapelable", “impecable” y "ejemplar".

\subsection{Contextualización}

En este análisis se evidenció que La República recurrió a la mención de los crímenes por los que fue juzgado Alberto Fujimori y a otros acontecimientos vinculados por los que se le cuestionó, desde su renuncia a la Presidencia de la República por fax, hasta las estratagemas que se dieron durante su gobierno para que el crimen cometido quedara en la impunidad. El diario explicó el papel cumplido por los actores involucrados en el caso, como los miembros del Grupo Colina y los magistrados responsables de hacer justicia. Presentó las pruebas en contra de los acusados, recurriendo a expertos y juristas; señaló los alcances del proceso judicial respecto a las audiencias que serían necesarias, acorde los indicios evaluados y los hechos probados. De esto, se puede colegir que para La República fue primordial recordar al lector que Alberto Fujimori no solo fue inculpado por los crímenes de La Cantuta y Barrios Altos, sino por otras acciones que violentaron la democracia en Perú y por las que recibió un juicio pertinente. 
En el diario El Comercio, por su parte, la contextualización más consistente se dio el día de la lectura del fallo judicial. El medio también explicó la naturaleza de los crímenes por los que fue juzgado Fujimori, así como los hechos producidos durante su mandato, empezando con el autogolpe del 2 de abril. Incluso ofreció un diccionario de términos judiciales para el mejor entendimiento del lector.

En ambos diarios hubo una omisión: ni siquiera se incidió en la identidad de las víctimas de La Cantuta. Podría decirse que se les representó como una cifra porque, si bien mencionaron sus nombres en alguna oportunidad, no se detalló qué carrera estudiaban, si tenían una familia, ni sus historias personales.

\subsection{Juicios y atribuciones en editoriales}

La sentencia por el caso La Cantuta tuvo en los editoriales de El Comercio un tratamiento diferente. En cuanto a los juicios y atribuciones a los actores de este hecho, se distinguió claramente a Fujimori como el hombre que estuvo al frente de un régimen que gobernó con base en el pragmatismo, que desarticuló a la organización terrorista Sendero Luminoso, también tuvo que responder ante los tribunales por sus actos, obligado y después de haber huido al extranjero. En el editorial "Una sentencia justa y severa que debe acatarse" (08/04/2009), se aseguró que "por decisión propia [Fujimori] se convirtió en dictador". El periódico insistió en la manera antidemocrática en que gobernó para convertirse "en autócrata, luego en dictador y después, como dice la sentencia, en asesino".

En cuanto al rol de los fujimoristas, la crítica fue bastante similar. A estos personajes se les atribuye la voluntad - evidentemente cierta - de no querer acatar el fallo si este era, como sucedió, desfavorable para su líder. Que buscaron recurrir a la Corte Internacional de Derechos Humanos, cuyas resoluciones el fujimorato había desconocido. El diario reprochó a Keiko Fujimori promover el desacato a la sentencia, lo cual la descalificaba como demócrata. Asimismo, tras la ratificación del fallo, aseveró: "No hay un ánimo revanchista ni lapidador como quiere hacer ver un sector del fujimorismo". Recalcó que los fujimoristas no debían "victimizarse, porque de ninguna manera les calza ni les corresponde" ese papel (05/01/2010).

Por el lado de los deudos de las víctimas, aunque no hay atribución directa a ellos, el periódico desaprueba tajantemente las movilizaciones en su contra por ser un atentado contra sus derechos. 
La República fue sumamente incisiva en su crítica al fujimorismo. Editorialmente, se presentó a Fujimori como desprovisto de argumentos para defenderse, de preferir repetir las mentiras del pasado, de guardar silencio sobre su ex asesor Vladimiro Montesinos y de no actuar ante la barbarie del grupo Colina, por lo que se le juzgó.

A los fujimoristas, al igual que en El Comercio, los criticó por protestar contra el fallo y les recordó los actos "deplorables" y de violencia verbal que incitaron contra los abogados y los familiares de las víctimas; les sugirió aprender de los deudos a respetar la justicia y sus decisiones.

Atribuyó a los familiares de las víctimas de La Cantuta la búsqueda de la justicia pues esta sentencia "revindica a las víctimas que por años fueron tildadas de terroristas en el desesperado afán de justificar esos asesinatos" tal como como aseguró en su editorial "Diecisiete años después..." (08/04/2009).

En resumen, ambos periódicos saludaron la sentencia a Alberto Fujimori como "un síntoma del fortalecimiento de la democracia y marca el día de la Independencia del Poder Judicial" (La República, 08/04/2009), y no solo como un "precedente para el respeto a los derechos humanos sino para el Poder Judicial peruano" (El Comercio, 05/01/2010).

\subsection{Las fotografías en portada}

FIGURA 9. Portadas al día siguiente de la lectura de la sentencia
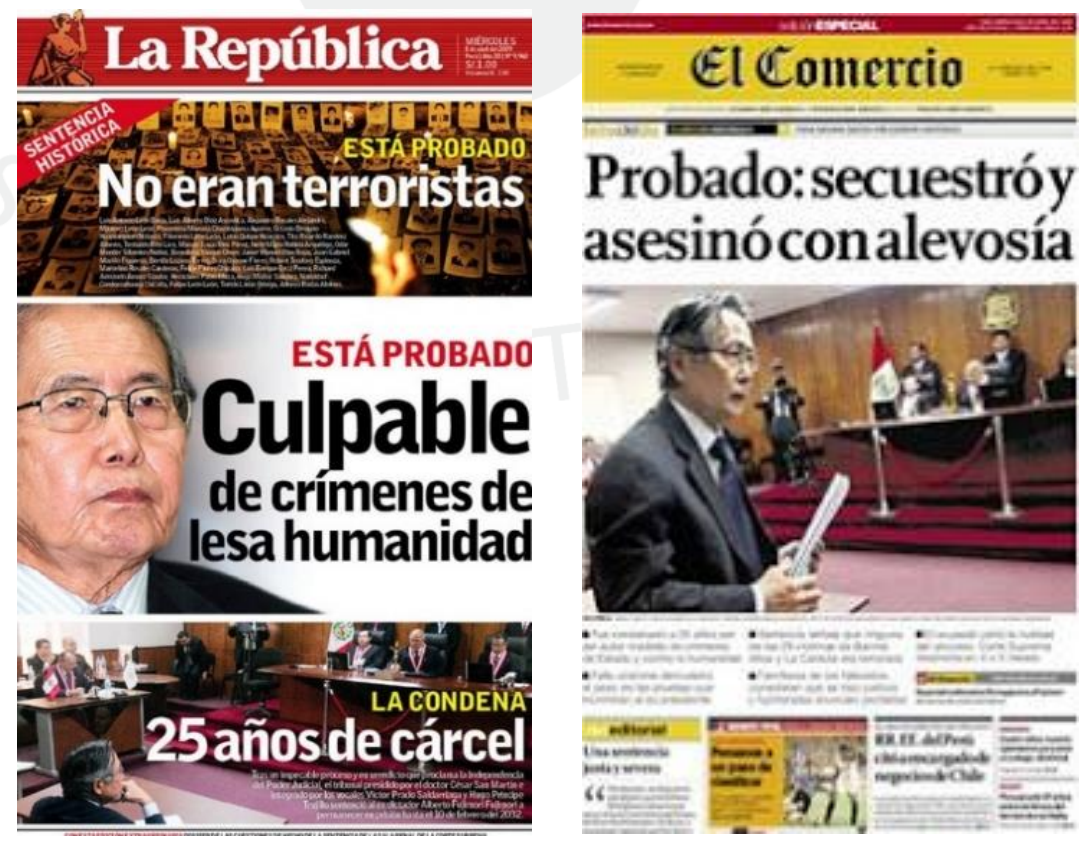
Tras la lectura de la sentencia, las portadas de los diarios ofrecieron elementos interesantes para el análisis gráfico de la información.

La portada modificada de La República, que de manera extraordinaria adoptó el formato de un diario estándar, se dividió en tres niveles y colocó en cada uno una fotografía. En el nivel central, destacó el rostro de Alberto Fujimori en primer plano acompañado del titular "Está probado. Culpable de crímenes de lesa humanidad". En el primer nivel se recurrió a la fotografía de una vigilia de los deudos de las víctimas de Barrios Altos y La Cantuta; mientras que, en el nivel inferior, apareció una imagen del juicio al expresidente.

Al colocar la fotografía de la vigilia en un espacio superior, por encima del rostro del exmandatario, este medio posiciona a las víctimas como actores protagónicos de la justicia en el país, y resulta muy revelador en tanto no solo se percibe la presencia de los familiares y su perseverante búsqueda de verdad y justicia, sino que, mediante los rostros de las víctimas en blanco y negro, obtenidos de documentos de identidad, constituye un instrumento de la memoria que testimonia que estas víctimas existieron y no fueron solo una cifra en la historia. En esta imagen hay una clara intención de evocación del recuerdo donde, por ejemplo, las velas, al tener un uso común en los lugares donde se intenta suscitar la memoria, pretenden con su encendido hacer presente a los ausentes (Ballesteros, 2014).

Por su parte, la fotografía del rostro de Fujimori apretando los labios, con una expresión un tanto nerviosa, bastante distante a la sonrisa que lo caracterizó en su campaña electoral en la década de 1990, demuestra la cara de la derrota, del culpable de la muerte de las víctimas de La Cantuta. De igual manera, en la foto inferior se le aprecia con las manos en la boca, en un signo de inseguridad, mientras la Sala Penal Especial de la Corte Suprema de la República emite su sentencia. Esta imagen se erige como un documento social de lo que fue y significará el juicio para historia.

La portada de El Comercio, a su vez, recurre a una fotografía a gran tamaño de Fujimori de perfil cuyo fondo son los magistrados que emitieron su sentencia. Se observa a un expresidente cabizbajo, encorvado, como si se aferrara a sus papeles, sabiéndose observado por todo el país. Se revela el triunfo de la verdad y la derrota de la violencia política, se percibe que el interés central es mostrar al victimario como nunca antes el país lo vio, condenado, abandonando su título de salvador que una de las memorias nacionales le imponía, y reivindicando la inocencia de quienes murieron bajo 
su mandato. Sin embargo, la ausencia de las fotografías de las víctimas da mayor protagonismo de Fujimori, perpetrador de los crímenes, respecto de otros de los actores del proceso y con ello el medio priva a los lectores y a la sociedad en conjunto de poder rememorar y comprender y, por tanto, de construir una memoria que las incluye.

\subsection{La posición de los actores involucrados}

¿Existe coincidencia entre la postura de los medios y la de los protagonistas de estas noticias? Martha Chávez (Anexo 8), una de las líderes del gobierno fujimorista, y Gisela Ortiz (Anexo 7), hermana de la víctima Enrique Ortiz y rostro representativo de los deudos de La Cantuta, tuvieron posiciones dispares respecto a la labor periodística cumplida en el cubrimiento de la sentencia, a su respectiva presencia como fuentes, a la contextualización y a la construcción de la memoria (Tabla 1).

Sin embargo, un aporte valioso para esta investigación, es que ambas entrevistadas, desde sus particulares posiciones, coincidieron en que ninguno de los dos diarios limeños contextualizó adecuadamente el caso, entendiendo 'contexto' como la presentación de los antecedentes y circunstancias ${ }^{1}$.

TABLA 1. Entrevista a Gisela Ortiz y Martha Chávez

\begin{tabular}{|c|c|c|}
\hline & Gisela Ortiz & Martha Chávez \\
\hline $\begin{array}{l}\text { Importancia de } \\
\text { la cobertura } \\
\text { periodística }\end{array}$ & $\begin{array}{l}\text { Gran parte de lo que se logra } \\
\text { en la justicia peruana tiene } \\
\text { que ver con la vigilancia de } \\
\text { los medios. }\end{array}$ & $\begin{array}{l}\text { Los medios influyeron en la } \\
\text { condena a Fujimori. Fue "un } \\
\text { juicio social, mediático, } \\
\text { político". }\end{array}$ \\
\hline $\begin{array}{l}\text { Rol } \\
\text { víct }\end{array}$ & $\begin{array}{l}\text { Reparación simbólica, } \\
\text { dignificación de víctimas }\end{array}$ & $\begin{array}{l}\text { "Los medios quisieron } \\
\text { santificar a esa gente". }\end{array}$ \\
\hline $\begin{array}{l}\text { Presencia como } \\
\text { fuentes }\end{array}$ & $\begin{array}{l}\text { "Tiene que ver con la posición } \\
\text { del medio y la validez y la } \\
\text { importancia que le dé al } \\
\text { testimonio de los familiares de } \\
\text { las víctimas. Reconocemos a } \\
\text { algunos medios como aliados. } \\
\text { La República desde el inicio". }\end{array}$ & $\begin{array}{l}\text { "Los medios deben ser } \\
\text { evaluados por cómo manejan } \\
\text { nuestra libertad indirectamente. } \\
\text { Si nos dan información sesgada } \\
\text { nos estaremos haciendo ideas y } \\
\text { opiniones y tomando } \\
\text { decisiones injustas". }\end{array}$ \\
\hline Contextualización & $\begin{array}{l}\text { "No se contó bien lo que pasó, } \\
\text { el antecedente era Tarata. } \\
\text { Tampoco hablaron de una } \\
\text { Cantuta intervenida } \\
\text { militarmente donde era } \\
\text { imposible que alguien entrara }\end{array}$ & $\begin{array}{l}\text { "No se contó bien porque no se } \\
\text { atrevieron a decir o a } \\
\text { interesarse en quienes eran } \\
\text { estas personas, había que } \\
\text { ocultar esa faceta perversa para } \\
\text { hacerlos más víctimas aún". }\end{array}$ \\
\hline
\end{tabular}

\footnotetext{
${ }^{1}$ Martha Chávez fue entrevistada para esta investigación el 18 de junio de 2015. En tanto a Gisela Ortiz se le pudo contactar el 10 de junio de 2015.
} 


\begin{tabular}{|c|c|c|}
\hline & o saliera y peor con carros". & \\
\hline $\begin{array}{c}\text { Construcción de } \\
\text { memoria }\end{array}$ & $\begin{array}{l}\text { "La República con mayor } \\
\text { convicción ha informado } \\
\text { desde siempre; El Comercio } \\
\text { no es que no tenga un } \\
\text { compromiso de construcción } \\
\text { de memoria, pero sobre } \\
\text { derechos humanos no ha sido } \\
\text { permanente, solo en casos } \\
\text { mediáticos o de mayor } \\
\text { importancia". }\end{array}$ & $\begin{array}{l}\text { "Por odio a Fujimori se han } \\
\text { olvidado y han querido ocultar } \\
\text { que en el gobierno de Alan } \\
\text { García hubo más episodios de } \\
\text { violaciones los derechos } \\
\text { humanos por las fuerzas del } \\
\text { orden, pero han tornado toda la } \\
\text { responsabilidad en } \\
\text { presidente Fujimori". }\end{array}$ \\
\hline
\end{tabular}

Fuente: Elaboración propia

Otra de las preguntas de esta investigación fue recabar el punto de vista de los periodistas para tratar de explicar por qué informaron en tal o cual sentido, para contrastar los cuestionamientos surgidos en el análisis de los contenidos². Ángel Páez de La República (Anexo 10) y Mario Mejía de El Comercio (Anexo 9) argumentaron cómo la sentencia a Fujimori sí fue un hecho que marcó la agenda de los ambos diarios; a qué se debió la predominancia del género informativo antes que el interpretativo, la adjetivación, las fuentes consultadas y la importancia otorgada a las víctimas en sus narraciones; finalmente, cómo construyeron memoria desde su labor y cuáles fueron las principales carencias en el cubrimiento (Tabla 2).

TABLA 2. Entrevista a Ángel Páez y Mario Mejía

\begin{tabular}{|c|c|c|}
\hline & Ángel Páez & Mario Mejía \\
\hline $\begin{array}{l}\text { El tema en la } \\
\text { agenda del } \\
\text { diario }\end{array}$ & $\begin{array}{l}\text { "Estuvo en la agenda de } L a \\
\text { República porque desde los } \\
\text { noventa; investigamos mucho el } \\
\text { caso Fujimori y también al } \\
\text { destacamento Colina". }\end{array}$ & $\begin{array}{l}\text { "Desde un comienzo se dijo que } \\
\text { se tenía que tratar con amplitud, } \\
\text { no podía pasar a segundo plano, } \\
\text { era de prioridad y siempre se le } \\
\text { dio ese tratamiento". }\end{array}$ \\
\hline $\begin{array}{l}\text { Predominancia } \\
\text { del género } \\
\text { informativo }\end{array}$ & $\begin{array}{l}\text { "Son más notas informativas, } \\
\text { solo publicábamos reportajes de } \\
\text { investigación cuando teníamos } \\
\text { algún ángulo novedoso. Eran dos } \\
\text { formas de cobertura: las noticias } \\
\text { cotidianas, los incidentes, el } \\
\text { proceso judicial, por un lado; y } \\
\text { los reportajes de investigación } \\
\text { periodística". }\end{array}$ & $\begin{array}{l}\text { "La inmediatez, había que dar } \\
\text { cuenta de qué estaba pasando, la } \\
\text { cantidad de información que se } \\
\text { daba era abundante, era un tema } \\
\text { noticioso. De vez en cuando } \\
\text { había otros géneros, se pedían } \\
\text { columnas para que analizaran, } \\
\text { se diera una interpretación del } \\
\text { tema". }\end{array}$ \\
\hline Fuentes & $\begin{array}{l}\text { "Recuerdo varias entrevistas al } \\
\text { señor Nakasaki, a políticos o } \\
\text { congresistas fujimoristas, pero no } \\
\text { en la dimensión que otros }\end{array}$ & $\begin{array}{l}\text { "Es una cuestión de practicidad. } \\
\text { Terminaba la audiencia y había } \\
\text { una rueda de prensa donde } \\
\text { hablaban las partes, el abogado }\end{array}$ \\
\hline
\end{tabular}

${ }^{2}$ La entrevista a Ángel Páez se realizó el 19 de junio de 2015; a Mario Mejía, el 10 de julio de 2015. 


\begin{tabular}{|c|c|c|}
\hline & $\begin{array}{l}\text { medios. Si revisas todos los } \\
\text { medios, en gran parte se le daba } \\
\text { más espacio a Fujimori y su } \\
\text { familia. La norma dice que el } \\
\text { espacio siempre es preferente } \\
\text { para las víctimas". }\end{array}$ & $\begin{array}{l}\text { de las víctimas, de la parte civil } \\
\text { y sobre todo el abogado de } \\
\text { Fujimori. Se recogía eso y por } \\
\text { la cuestión de que había que } \\
\text { inmediatamente volver al } \\
\text { diario" }\end{array}$ \\
\hline Adjetivos & $\begin{array}{l}\text { "Tendríamos que ver el contexto, } \\
\text { pero el término apropiado para } \\
\text { este señor [Fujimori] fue dictador } \\
\text { porque el } 5 \text { de abril de } 1992 \\
\text { instaló un régimen militar". }\end{array}$ & $\begin{array}{l}\text { "El Comercio trató de no } \\
\text { adjetivar. En notas se ponía 'ex } \\
\text { presidente', 'el sentenciado'; en } \\
\text { los editoriales sí se ponía todos } \\
\text { los adjetivos, pero en la parte } \\
\text { noticiosa se trataba de ser lo } \\
\text { más objetivos, no era una } \\
\text { intención de querer suavizarlo. } \\
\text { Recién con el juicio se iba a } \\
\text { saber la culpabilidad". }\end{array}$ \\
\hline Víctimas & $\begin{array}{l}\text { "La línea del periódico consiste } \\
\text { en dar espacio a los que son } \\
\text { víctimas, de los que se abusa de } \\
\text { sus derechos y a los que se le ha } \\
\text { asesinado a un familiar, con la } \\
\text { finalidad de que se conozca su } \\
\text { punto de vista". }\end{array}$ & $\begin{array}{l}\text { "Era una de las cosas } \\
\text { trascendentales que dio el fallo, } \\
\text { el reconocer a esas víctimas que } \\
\text { por mucho tiempo se les dijo } \\
\text { terroristas. Ese era uno de los } \\
\text { puntos vitales, aparte la dureza } \\
\text { que tuvo la sentencia". }\end{array}$ \\
\hline $\begin{array}{l}\text { Construcción } \\
\text { de memoria }\end{array}$ & $\begin{array}{l}\text { "Aplicamos los fundamentos de } \\
\text { nuestro trabajo que consiste en la } \\
\text { búsqueda de verdad, en conseguir } \\
\text { fuentes, evidencia, documentos, } \\
\text { testigos, así como confrontarlos, } \\
\text { verificarlos con un afán } \\
\text { movilizado por el interés público, } \\
\text { por el derecho de los ciudadanos } \\
\text { a saber realmente lo que ocurrió. } \\
\text { El medio construyó memoria } \\
\text { entendiéndose como el acceso de } \\
\text { las personas a conocer la verdad } \\
\text { de los hechos". }\end{array}$ & $\begin{array}{l}\text { "Sí, pero hay tantos anticuerpos } \\
\text { contra el diario y bueno } \\
\text { obviamente tampoco no se } \\
\text { resalta en él ese punto, sí tiene } \\
\text { su importancia; no se da como } \\
\text { en La República que ellos sí, } \\
\text { por la línea en la que están, } \\
\text { siempre resaltan más eso y la } \\
\text { gente lo nota". }\end{array}$ \\
\hline Carencia & $\begin{array}{l}\text { "La mayor cobertura fue para la } \\
\text { familia Fujimori, casi todos los } \\
\text { medios iban detrás de la señora } \\
\text { Fujimori; de los familiares de las } \\
\text { víctimas se olvidaban, como si } \\
\text { fueran subalternos cuando en } \\
\text { realidad son más importantes } \\
\text { porque son víctimas". }\end{array}$ & $\begin{array}{l}\text { "Quizás tener más equipo, ser } \\
\text { un equipo mayor para ver más y } \\
\text { analizar más el tema". }\end{array}$ \\
\hline
\end{tabular}

Fuente: Elaboración propia

En este intento por hallar explicaciones al discurso de los medios, este artículo contrastó los resultados obtenidos con el presidente de la Comisión de la Verdad y Reconciliación en Perú, Salomón Lerner Febres (Anexo 11), quien destacó la importancia de la voz de 
las víctimas en las narraciones del pasado de violencia en la prensa nacional pues "la palabra primera la tienen las víctimas, no puede ser la historia de los victimarios o de gente neutra entre comillas, porque en este asunto no hay gente neutra. La neutralidad es un absurdo, uno tiene que estar con quien es inocente, es víctima”, y precisó que "son ellos quienes nos tienen que decir cómo han sufrido, porque de otro modo no vamos a tomar conciencia de la realidad del país, del estado en el cual se encontraban. Las víctimas tienen por lo menos el derecho a decir su verdad"3.

Lerner enfatizó que, de los dos diarios limeños, "La República ha estado un poco más (presente), pues ha tenido gente suya que ha sido víctima. En ese sentido, tuvo bastante más sensibilidad que la que ha tenido El Comercio".

Respecto a la construcción de la memoria en la prensa, Lerner aseguró que los diarios "se han quedado en una cuestión de memoria pero que es previa; ver si hubo o no delito, qué es lo que ocurrió, cuál fue la conducta de los militares en todo este asunto y la vinculación con el poder establecido". La cuestión humana, ir a ver quiénes eran los alumnos, qué era realmente lo que ellos pensaban, cuáles eran sus nombres, no se cubrió. En este sentido, "fue una memoria pequeñita y un poco manejada [...] Falta por lo menos en Perú un periodismo más reflexivo, más dialogante, que invite más a pensar las cosas".

\footnotetext{
${ }^{3}$ Se entrevistó al doctor Salomón Lerner Febres el 23 de junio de 2015.
} 


\section{DISCUSIÓN}

De las consideraciones iniciales en este artículo, la investigación demostró que efectivamente la cobertura mediática sobre la sentencia a Alberto Fujimori en los diarios limeños El Comercio y La República fue significativa ya que, como enunciaron sus periodistas, fue un tema que marcó sus respectivas agendas y, en cierta medida, contribuyó al fortalecimiento de ese contexto de transición hacia la reconciliación que aún vive el país luego del conflicto armado interno.

El amplio despliegue noticioso desarrollado por La República corrobora en síntesis los principios editoriales que enarbola, como la defensa de los derechos humanos y la visibilización de toda persona que resulte víctima o se vea avasallada por el abuso de terceros. Tal convicción no es interpretada de la misma manera por $E l$ Comercio que, en el caso analizado, hizo una cobertura más distante respecto a lo ocurrido. No desconoció la magnitud de la denuncia, si se revisa lo publicado sobre todo después de que el Poder Judicial sentenció ejemplarmente a Fujimori, pero no se comprometió con el tema a profundidad si se evalúan los espacios que concedió al tema. Según los Principios Rectores de El Comercio (2006), en vigencia cuando sucedieron los hechos, este diario - al igual que La República - defiende a quienes han visto vulnerados o amenazados sus derechos, pero se podría afirmar que su lectura es más legalista que social.

Sobre el tratamiento dado a las fuentes de información puede señalarse que, al no leerse ninguna declaración de los deudos de las víctimas, tan solo de sus abogados, El Comercio desestimó el valor del testimonio de los familiares, como fuentes centrales al narrar este proceso de justicia transicional, a pesar de definirse en sus propios principios rectores como "partidario de una cultura de paz" (2006, p. 21). Según redactores consultados, la inmediatez a la hora de informar sobre un hecho tan complejo habría impedido dar esa cobertura. No obstante, cabe preguntarse si la posición de algunos directivos de la corporación, comprometidos políticamente con un sector del fujimorismo, fue un factor que ocasionó desconocer a quienes tenían una voz que debió aparecer en las páginas de un diario de referencia como El Comercio. Por tanto, en cierta medida, invisibilizó a las víctimas en sus páginas informativas y arrebató la posibilidad de contar lo ocurrido mediante sus familiares para reconfigurar una memoria que cuestione y supere la historia considerada oficial. ¿Cuáles son las consecuencias de este tratamiento de la información en los medios de comunicación? 
Un problema es que muchas veces esta 'historia oficial' es la socialmente aceptada y difundida por años (Delgado, 2014, p.77), aunque la prensa puede hacer que el sufrimiento vivido tenga un propósito pues "una vez que el periodista la consulta y la incluye en la narrativa le genera a la víctima la sensación de reinclusión en una sociedad que la debía proteger y que, al momento de cometerse el acto traumático, pareció no hacerlo" (FLIP, 2009, p. 20).

En unos años, cuando se reescriba la historia de La Cantuta, una pregunta será: ¿y quiénes eran las víctimas? Lo cierto es que Perú se halla todavía muy lejos de velar por sus desaparecidos. Como señala el Manual de Periodismo y Justicia Transicional (2009), muchas veces los abusos contra los derechos humanos parecen referir la historia de los victimarios cuando, en su lugar, a los medios podrían perennizar la diversidad de las memorias; "víctimas y victimarios no reconstruyen una misma memoria y tampoco cuentan con los mismos recursos para hacerlo, hecho que incide en las posibilidades que se tenga de visibilizarlas" (Sánchez, 2010, p.88). Al cubrir un proceso de transición como este, el aporte de los diarios es muy valioso hacia un debate más inclusivo en los lectores donde se ponderen las versiones tanto de víctimas como de victimarios, con un interés central por la memoria de quienes ya no están: "no es suficiente que los medios visibilicen a las víctimas y se muestren benevolentes frente a sus historias de vida. También es necesario que estas se conviertan en una fuente indispensable para cubrir los hechos y entender cuáles fueron los procesos y lógicas de victimización a los cuales se vieron sometidas" (FLIP, 2009, p.39).

Respecto al fondo del asunto - la sentencia-, las páginas informativas de ambos diarios defendieron la trascendencia de una justa decisión de la justicia contra Fujimori por los delitos de lesa humanidad de su gobierno. La República, evidentemente, condenó abiertamente al exmandatario con calificativos como "ex dictador", mientras El Comercio, mantuvo su histórica objetividad para referirse a él, sobre todo antes de la sentencia, toda vez que no existía un fallo que justificase tildarlo de autócrata. En tal postura, el diario pudo refutar los argumentos del fujimorismo en cuanto a que no existió una intención de "aniquilar al adversario".

No obstante, cabe mencionar que editorialmente ambos diarios defendieron el respeto de los derechos humanos a través de la búsqueda de justicia y verdad sobre lo ocurrido en La Cantuta, expusieron una postura decidida y condenatoria sobre Fujimori y el accionar de sus partidarios en contra de los familiares de las víctimas y de la búsqueda de justicia. 
Las portadas de ambos medios merecen una lectura aparte. Se rescata que al reconocer en sus primeras páginas la inocencia de las nueve víctimas de La Cantuta, tanto El Comercio como La República recrearon una reparación simbólica y una dignificación de los desaparecidos que una memoria en el país intentó silenciar por mucho tiempo, como lo explicó Gisela Ortiz en la entrevista concedida para esta investigación. Así, esta decisión adoptada desde la dirección de los dos medios demostró la importancia y la necesidad del reconocimiento de la memoria de las víctimas ante los lectores y la sociedad en su conjunto, como garantía de que su sufrimiento y su historia no se repetirán.

De esta manera, este estudio considera que ambos periódicos tuvieron la intención y la vocación de seguir y vigilar el proceso judicial contra Fujimori, aunque en ocasiones estas no se reflejaran en las páginas informativas y de opinión. En este caso, por ejemplo, coexistieron con carencias en el tratamiento y quehacer periodístico que debilitaron la construcción de una memoria totalmente reivindicativa para las víctimas en beneficio de un clima de reconciliación nacional.

Además de la mencionada ausencia del testimonio de los deudos de las víctimas, las deficiencias en la contextualización de los hechos fueron inadmisibles en la cobertura. Ambos diarios publicaron los nombres de las víctimas, pero no ahondaron en sus identidades. No detallaron que hacían exactamente cuando ocurrió su desaparición y su posterior ejecución o cuál era el ambiente militar que vivía la universidad La Cantuta en esa época. Tampoco se recordó que su desaparición estuvo asociada al atentado de la calle Tarata, ni se reparó en cuáles eran sus sueños como jóvenes estudiantes que eran antes de que la violencia los aniquilara. Esta información circuló en otros medios de prensa. Los retratos de las víctimas en La República han quedado como prueba de que los estudiantes Juan Gabriel Mariños Figueroa (32), Heráclides Pablo Meza (28), Robert Édgar Teodoro Espinoza (24), Armando Richard Amaro Cóndor (25), Luis Enrique Ortiz Perea (21), Dora Oyague Fierro (21), Felipe Flores Chipana (25), Bertila Lozano Torres (21), Marcelino Rosales Cárdenas y el profesor Hugo Muñoz Sánchez (47) sí existieron y fueron sometidos a un cruento e indiferente pasado.

Este trabajo considera que tanto la inclusión del contexto como las fotografías de las víctimas pudo haber resuelto las preguntas sobre el por qué la historia nacional desembocó en un estado de vulneración de los derechos humanos, y sensibilizar, así, a la sociedad peruana sobre los efectos de la violencia como un atentado a la democracia. 
En otras palabras, si los diarios de mayor influencia en el país hubieran construido un relato que articulase el perfil y las historias de quienes murieron a manos de paramilitares, probablemente se hubiera sumado un aporte para sensibilizar al lector en la recordación de esta experiencia y del cuestionamiento de las versiones relatadas desde el fujimorato. Presentar el contexto permite que se construya un juicio y una memoria sobre lo acontecido; que se entiendan los hechos no solo como casos aislados. La utilización de las fotografías de las víctimas fue también una oportunidad desperdiciada porque más allá de mostrarnos los rostros de quienes fueron consideradas como un número más en la cifra nacional que dejó el conflicto, hubiera comprendido una construcción de la memoria, "de un saber en tanto deja rememorar, reconstruir, comprender, acercarnos, ya que posibilita la constitución de una serie de relaciones entre lo que sabemos, lo que vemos y lo que podemos imaginar" (Herrera y Olaya, 2014, p. 93) de ese doloroso capítulo de nuestra historia como país.

Frente a esto, llama la atención la escasa preocupación en los diarios por enfatizar el uso del género interpretativo en el cubrimiento de los juicios luego del conflicto armado interno. Ni la inmediatez ni la falta de periodistas asignados a la cobertura de un proceso judicial de esta magnitud, sin mencionar otros juicios menos mediáticos como el que inició este año contra los militares acusados de las violaciones a 14 mujeres de las comunidades de Manta y Vilca entre 1984 y 1989, deberían ser factores que determinen un periodismo carente de reflexión y menos dialogante, parafraseando a Lerner Febres; sino que desde las direcciones de los medios se debe optar por desplegar sus esfuerzos hacia un cubrimiento que permita a los lectores repensar el pasado y las memorias que por tantos años se vieron silenciadas, marginadas y, así, expresar una resistencia al olvido.

¿Los medios contribuyeron a construir una memoria a partir de la sentencia a Fujimori en el Caso La Cantuta? ¿Si fue así, de qué tipo de memoria hablamos? Como señala Barrantes y Peña (2006), los medios de comunicación son agentes afines a una u otra memoria, lo cual no solo orienta sus líneas editoriales, sino cómo presentan las noticias. El análisis señala que ambos diarios aportaron a la construcción de una memoria que condenó al exmandatario. La República se aproximó a la narración de una memoria de reconciliación en cuanto cuestionó la memoria de salvación, es decir, a esa visión del pasado que sintoniza con la impunidad ya que justifica los crímenes cometidos como inevitables. Este medio se alinea a esta memoria donde la revelación de lo que sucedió en el país es prioridad partiendo desde las responsabilidades por las 
violaciones de los derechos humanos y apelando al recuerdo de otros casos que evidencian la existencia de un sistema de crímenes de lesa humanidad. Tanto en sus espacios informativos como de opinión, La República priorizó el desmentido de las falacias de los perpetradores, la atribución de responsabilidades y el cuestionamiento de una memoria que había legitimado la violencia de Estado como el único camino hacia la paz en el país. Este estudio, sin embargo, considera que dicho medio no debió acallar la memoria de salvación en sus notas y reportajes con una menor presencia de fuentes fujimoristas, sino que, en su lugar, debió cuestionarlas con los testimonios de los deudos de las víctimas y las revelaciones que presenta el Informe Final de la CVR, en un ejercicio que demuestra la importancia de la pluralidad de voces para comprender el pasado, tal y como sí sucedió en sus respectivos editoriales.

En cuanto a El Comercio, el trabajo de la memoria en su cobertura presentó una contradicción: por una parte, en sus notas informativas, al darle más voz a los fujimoristas y a otras fuentes judiciales antes que a las declaraciones de los deudos de La Cantuta, se reconstruyó una suerte de memoria de salvación; no obstante, al cuestionar tajantemente a Fujimori y a los delitos de su gobierno en sus editoriales, este medio se aproximó a una memoria de reconciliación. De este modo, esta antítesis en la que se invisibilizó a los familiares de las víctimas en las informaciones pudo confundir al lector con relatos sesgados como si fueran una versión fidedigna, como si se tratara, una vez más, de la historia de los perpetradores.

Un punto de coincidencia en la construcción de memoria en ambos periódicos limeños descansa en cómo se acercaron a una memoria de reconciliación. Tanto $L a$ República como El Comercio perfilaron una memoria previa, para utilizar la definición de Lerner Febres, pues, aunque el pasado deja huellas mnésicas en nuestra dinámica psíquica y en nuestro mundo simbólico, por sí solas no son memorias a menos que sean evocadas y ubicadas en un marco que les dé sentido (Jelin, 2002). El trabajo periodístico de ambos diarios ha formado el camino para acceder a tales huellas, justamente, develando, sacando a la luz lo encubierto, superando todo impedimento político, toda represión que no nos permita recuperar las memorias legítimas y verdaderas en el futuro.

Aprender de estas experiencias puede permitir a los periodistas y comunicadores cubrir acontecimientos futuros que comprometen la justicia transicional, que aún están por darse en Perú, como es la posibilidad de un indulto humanitario a Alberto Fujimori o la búsqueda de las casi 16 mil personas desaparecidas que, gracias a 
la recién promulgada Ley de búsqueda de personas desaparecidas durante el periodo de violencia 1980-2000, merecen ser halladas. Una oportunidad que nos ha comenzado a poner a prueba como colectividad es el Lugar de la Memoria, un espacio que, como sucede en otros países sumidos en la violencia, puede contribuir al encuentro y reconocimiento de la pluralidad de memorias legítimas y verdaderas para alcanzar, así, la rememoración y la reflexión del conflicto con un profundo recuerdo de todos nuestros muertos, sean civiles y militares.

La reconciliación nacional es un proceso que aún, 15 años después del Informe Final de la CVR, se complejiza por las maneras en que las memorias sobre nuestro pasado reciente se enfrentan en nuestra sociedad. Por este camino, el periodismo peruano puede aportar con su trabajo a la reconciliación nacional mediante la consolidación de una memoria inclusiva, la reafirmación de los procesos democráticos y el resguardo de los derechos humanos como principios humanitarios en un proyecto de futuro como nación. 


\section{REFERENCIAS}

Acevedo, K. (2012). "El periodismo y la sentencia de Alberto Fujimori por los crímenes de La Cantuta y Barrios Altos". Cobertura y tratamiento de la noticia en los diarios: El Comercio, Trome, La República, El Popular, Correo y Ajá. Lima: Pontificia Universidad Católica del Perú. Recuperado de http://tesis.pucp.edu.pe/repositorio/handle/123456789/1278

Ballesteros, E. (2014). Usos sociales de las velas. Aproxmaciones desde el análisis de materiales visuales. Madrid: Universidad Complutense. Recuperado de http://eprints.sim.ucm.es/25674/

Barbosa, M. (2004). Jornalistas, "senhores da memória"? En NP 02 - Jornalismo do IV Encontro dos Núcleos de Pesquisa da Intercom. Porto Alegre: Intercom. Recuperado de http://portcom.intercom.org.br/revistas/index.php/revistainter com/article/viewFile/1259/1212

Barrantes, R., \& Peña, J. (2006). Narrativas sobre el conflicto armado interno en el Perú: la memoria en el proceso político después de la CVR. En Transformaciones democráticas y memorias de la violencia en el Perú. Lima: Instituto de Democracia y Derechos Humanos. Recuperado de http://idehpucp.pucp.edu.pe/images/publicaciones/tranformaciones_democratica s_y_memorias_violencia_peru.pdf

Comisión de la Verdad y Reconciliación (CVR). (2003). Informe final de la CVR. Lima: CVR.

Cosme, C., Jaime, M., Merino, A., \& Rosales, J. (2007). La imagen in/decente. Diversidad sexual, prejuicio y discriminación en la prensa escrita peruana. Lima: Instituto de Estudios Peruanos.

Degregori, C. (2004). Heridas abiertas, derechos esquivos: Reflexiones sobre la Comisión de la Verdad y Reconciliación. En Memorias en conflicto. Aspectos de violencia política contemporánea. Lima: Embajada de Francia en el Perú.

Degregori, C. (2013). La década de la antipolítica. Auge y huida de Alberto Fujimori y Vladimiro Montesinos. Lima: Instituto de Estudios Peruanos.

Delgado, M. (2014). Memoria, conflicto armado y justicia transicional: las voces de las víctimas en la reconstrucción del pasado (COLOMBIA, 2005-2012). Revista Historia y Justicia, 59 - 88.

El País. (2014). Géneros periodísticos. En Libro de estilo. México D.F.: Aguilar.

El Comercio. (2006). Principios Rectores para sus diarios y revistas. Lima: Impresiones Comerciales Amauta. 
Fisas, V. (2006). Una cultura de paz. En Cultura de paz y gestión de conflictos . París: Ediciones UNESCO. Recuperado de http://escolapau.uab.cat/img/programas/ cultura/una_cpaz.pdf

Fundación Ideas para la Paz (FIP). (2008). Cuadernos del conflicto. Verdad, memoria histórica y medios de comunicación. Bogotá: Publicaciones SEMANA. Recuperado de http://www.ideaspaz.org/publications/posts/106

Fundación para la Libertad de Prensa (FLIP). (2009). Manual sobre periodismo y justicia transicional. Bogotá: Editora Géminis. Recuperado de http://flip.org.co/sites/default/files/archivos_publicacion/Manual\%20sobre\%20P eriodismo\%20y\%20Justicia\%20Transicional.pdf

Gastaminza, F. D. (2002). Dimensión documental de la fotografía. Congreso Internacional sobre Imágenes e Investigación Social. Madrid: Universidad Complutense de Madrid. Recuperado de http://pendientedemigracion.ucm.es/ info/multidoc/prof/fvalle/Confemex.htm

Grijelmo, Á. (2006). Géneros periodísticos. En El estilo del periodista (2 ed.). México D.F.: Taurus.

Hernández, R., Fernández, C., \& Baptista, M. (2010). Metodología de la investigación (5ta ed.). México D.F.: Mc Graw-Hill e Interamericana Editores.

Hernando, L. A. (2001). Lengua y estilo del editorial. Estudios sobre el mensaje periodístico, ed. 7. Recuperado de http://pendientedemigracion.ucm.es/ info/emp/Numer_07/7-5-Inve/7-5-07.htm\#abstract

Jelin, E. (2002). ¿De qué hablamos cuando hablamos de memoria? En Los trabajos de la memoria . Madrid: Siglo XXI de España Editores.

Jelin, E. (2003). Memorias y luchas políticas. En C. Degregori, Jamás tan cerca arremetió lo lejos: memoria y violencia política en el Perú. Lima: Instituto de Estudios Peruanos.

Mendoza, M. (2013). 100 años de periodismo en el Perú (1949 - 2000). Lima: Universidad de Lima.

Naciones Unidas (UN). (2004). El Estado de derecho y la justicia de transición en las sociedades que sufren o han sufrido conflictos. En Informe del Secretario General al Consejo de Seguridad de Naciones Unidas. Recuperado de http://www.un.org/es/comun/docs/?symbol=S/2004/616

Herrera, M., \& Olaya, V. (2014). Fotografía y violencia: la memoria actuante de las imágenes. Cuadernos de Música, Artes Visuales y Artes Escénicas, 89-106. Recuperado de http://www.redalyc.org/pdf/2970/297040437005.pdf 
Oviedo, C. (1989). Prensa y subversión: una lectura de la violencia en el Perú. Lima: Hipatía.

Pellegrini, S. (2006). Valor Agregado Periodístico (VAP): la calidad periodística como un factor productivo en un entorno medial complejo. Recuperado de http://www.redalyc.org/pdf/649/64900101.pdf

Prado, B. (2014). A cinco años de la sentencia a Alberto Fujimori. Lima: IDEHPUCP. Recuperado de http://idehpucp.pucp.edu.pe/comunicaciones/opinion/cincoanos-de-la-sentencia-alberto-fujimori/

Proyecto Antonio Nariño. (2004). Calidad informativa y cubrimiento del conflicto. Estándares de calidad periodística en el cubrimiento del conflicto en Colombia. Bogotá: Fondo Editorial CEREC.

Ricoeur, P. (2004). La memoria, la historia, el olvido. Buenos Aires: Fondo de Cultura Económica.

Sánchez, G. (2010). Los victimarios ante los estrados judiciales. Revista Análisis Político, 18(54), 81- 87. Recuperado de http://www.scielo.org.co/ scielo.php?script=sci_arttext $\&$ pid=S0121-47052010000100009

Sorensen, K. (2015). Los medios, la memoria y los derechos humanos en Chile. Santiago de Chile: Ril editores.

Teramo, M. (2006). Calidad de la información periodística en Argentina. Estudio de diarios y noticieros. Bogotá: Universidad de La Sabana. Recuperado de https://robertoigarza.files.wordpress.com/2008/11/art-analisis-de-la-calidadperiodistica-en-argentina-teramo-2006.pdf

Todorov, T. (2000). La memoria amenazada. En Los abusos de la memoria. Barcelona: Paidós. 


\section{BIBLIOGRAFÍA}

Assad de Moraes, L. (2014). Ditadura militar: a memória jornalística como parte da revisão histórica. Revista Brasileira de História da Mídia (RBHM). Recuperado de http://www.unicentro.br/rbhm/ed06/dossie/03.pdf

Centro Internacional para la Justicia Transicional (ICTJ). (s.f.). El juicio de Alberto Fujimori. Lima. Recuperado el 13 de Julio de 2016, de https://www.ictj.org/sites/default/files/ICTJ-Peru-Fujimori-Trial-2008Spanish.pdf

Centro Internacional para la Justicia Transicional (ICTJ). (s.f.). Verdad y Memoria. Recuperado el 12 de Julio de 2016, de https://www.ictj.org/es/ourwork/transitional-justice-issues/verdad-y-memoria

Centro Nacional de Memoria Histórica (CNMH). (2013). Recordar y narrar el conflicto. Bogotá: Centro Nacional de Memoria Histórica y University of British Columbia. Recuperado de http://www.centrodememoriahistorica.gov.co/ descargas/informes2009/recordar-narrar-el-conflicto.pdf

Franco, N., Nieto, P., \& Rincón, O. (2010). Las narrativas como memoria, conocimiento, goce e identidad. En Tácticas y estrategias para contar. Historias de la gente sobre conflicto y reconciliación. Bogotá: Centro de Competencia en Comunicación para América Latina. Recuperado de http://library.fes.de/pdffiles/bueros/c3-comunicacion/07391.pdf

Fundación Social. (2006). Guía sobre Reconciliación: Claves para la Construcción de un Horizonte en Colombia. Bogotá: Fundación Social . Recuperado de http://datateca.unad.edu.co/contenidos/753003/Guia_sobre_reconciliacion.pdf

Lerner Febres, S. (2004). Epílogo . En Memorias en conflicto. Aspectos de violencia política contemporánea. Lima : Embajada de Francia en el Perú.

Manrique, N. (2003). Memoria y violencia. La nación y el silencio. En H. Marita, Batallas por la memoria: antagonismos de la promesa peruana (págs. 421-433). Lima: Red para el desarrollo de las Ciencias Sociales en el Perú.

Ministerio del Interior y de Justicia. (2011). Justicia Transicional. Aportes para construir un lenguaje unificado de transición en Colombia. Bogotá: Editorial Milla. Recuperado de http://www.corteidh.or.cr/tablas/29500.pdf

Morelo, G., Castrillón, G., \& Behar, O. (2014). Pistas para narrar la paz. Periodismo en el posconflicto. Bogotá: Fundación Konrad Adenauer y Consejo de Redacción. Recuperado de http://www.kas.de/wf/doc/kas_40811-1522-430.pdf?150325165242 
Naciones Unidas (UN). (2014). Justicia Transicional y derechos económicos, sociales y culturales. Nueva York y Ginebra: Naciones Unidas Derechos Humanos. Recuperado de http://www.ohchr.org/Documents/Publications/HR-PUB-1305_sp.pdf

Pellegrini, S. (1999). Medición de la calidad de la prensa en Chile. Santiago de Chile: Escuela de Periodismo de la Pontificia Universidad Católica de Chile. Recuperado de https://dialnet.unirioja.es/descarga/articulo/2938501.pdf

Reátegui, F. (Ed.). (2011). Justicia transicional: manual para América Latina. Brasilia: Comisión de Amnistía del Ministerio de Justicia de Brasil. Recuperado de http://idehpucp.pucp.edu.pe/wp-content/uploads/2012/12/Manual-JusticiaTransicional-espa\%C3\%B1ol-versi\%C3\%B3n-final-al-21-05-12-5-1.pdf

Stern, S. (1999). De la memoria suelta a la memoria emblemática: Hacia el recordar y el olvidar como proceso histórico (Chile, 1973-1998). Recuperado de: http://www.cholonautas.edu.pe/modulo/upload/SStern.pdf 
ANEXOS 
ANEXO 1: Lista total de portadas de La República

\begin{tabular}{|c|c|c|c|}
\hline Fecha & Medio & Hito & Titular \\
\hline 03/04/2009 & La República & Previo a la sentencia & $\begin{array}{l}\text { Que hoy diga la verdad } \\
\text { (Familiares de las víctimas } \\
\text { emplazan a Fujimori) }\end{array}$ \\
\hline $04 / 04 / 2009$ & La República & Previo a la sentencia & 7 de abril día de la sentencia \\
\hline $05 / 04 / 2009$ & La República & Previo a la sentencia & $\begin{array}{l}\text { Intenso debate (Alistan } \\
\text { sentencia a Fujimori) }\end{array}$ \\
\hline 06/04/2009 & La República & Previo a la sentencia & $\begin{array}{l}\text { Perdió juicio ciudadano } \\
\text { (Fujimori a un día de la } \\
\text { sentencia) }\end{array}$ \\
\hline $07 / 04 / 2009$ & La República & La sentencia & Sentencia histórica \\
\hline $08 / 04 / 2009$ & La República & La sentencia & $\begin{array}{l}\text { No eran terroristas / Culpable } \\
\text { de crímenes de lesa } \\
\text { humanidad / } 25 \text { años de } \\
\text { cárcel }\end{array}$ \\
\hline $09 / 04 / 2009$ & La República & La sentencia & $\begin{array}{l}\text { El mundo los llena de elogios } \\
\text { (Ejemplar sentencia enaltece } \\
\text { al Perú) }\end{array}$ \\
\hline $10 / 04 / 2009$ & La República & La sentencia & $\begin{array}{l}\text { Ahora al banquillo por } \\
\text { corrupción }\end{array}$ \\
\hline $12 / 04 / 2009$ & La República & La sentencia & $\begin{array}{l}\text { Las pruebas que sustentan la } \\
\text { sentencia }\end{array}$ \\
\hline $02 / 01 / 2010$ & La República & $\begin{array}{l}\text { La sentencia } \\
\text { (ratificación) }\end{array}$ & $\begin{array}{l}\text { Inminente sentencia } \\
\text { (Ratificarían fallo del juez } \\
\text { San Martín) }\end{array}$ \\
\hline 03/01/2010 & La República & $\begin{array}{l}\text { La sentencia } \\
\text { (ratificación) }\end{array}$ & $\begin{array}{l}\text { Confirmado: Es culpable } \\
\text { (Sala ratifica sentencia a } \\
\text { Fujimori) }\end{array}$ \\
\hline $04 / 01 / 2010$ & La República & $\begin{array}{l}\text { La sentencia } \\
\text { (ratificación) }\end{array}$ & $\begin{array}{l}\text { La Sentencia (Claves del fallo } \\
\text { de la Corte Suprema) }\end{array}$ \\
\hline
\end{tabular}

ANEXO 2: Lista total de portadas de El Comercio

\begin{tabular}{|c|c|c|l|}
\hline Fecha & Medio & \multicolumn{1}{c|}{ Hito } & \multicolumn{1}{c|}{ Titular } \\
\hline $07 / 04 / 2009$ & El Comercio & La sentencia & Que se haga justicia \\
\hline $08 / 04 / 2009$ & El Comercio & La sentencia & $\begin{array}{l}\text { Probado: secuestró y asesinó } \\
\text { con alevosía }\end{array}$ \\
\hline $09 / 04 / 2009$ & El Comercio & La sentencia & $\begin{array}{l}\text { Fujimoristas quieren } \\
\text { manipular la sentencia }\end{array}$ \\
\hline $04 / 01 / 2010$ & El Comercio & $\begin{array}{l}\text { La sentencia } \\
\text { (ratificación) }\end{array}$ & $\begin{array}{l}\text { Reafirman condena de 25 } \\
\text { años a Fujimori sin opción a } \\
\text { indulto }\end{array}$ \\
\hline $05 / 01 / 2010$ & El Comercio & $\begin{array}{l}\text { La sentencia } \\
\text { (ratificación) }\end{array}$ & $\begin{array}{l}\text { Caso de Fujimori está cerrado } \\
\text { y no procede apelación }\end{array}$ \\
\hline
\end{tabular}


ANEXO 3: Lista total de publicaciones de La República

\begin{tabular}{|c|c|c|c|c|}
\hline Fecha & Hito & Titular & Tipo de nota & Firma \\
\hline 03/04/2009 & $\begin{array}{l}\text { Previo a la } \\
\text { sentencia }\end{array}$ & $\begin{array}{lcr}\text { Familiares } & \text { de } & \text { las } \\
\text { víctimas exigen } & \text { a } \\
\text { Fujimori que diga la } \\
\text { verdad }\end{array}$ & Reportaje & $\begin{array}{l}\text { Francesca } \\
\text { García }\end{array}$ \\
\hline 04/04/2009 & $\begin{array}{c}\text { Previo a la } \\
\text { sentencia }\end{array}$ & $\begin{array}{l}\text { El } 7 \text { de abril dictarán } \\
\text { sentencia a Fujimori } \\
\text { por violación de } \\
\text { DDHH }\end{array}$ & Reportaje & $\begin{array}{l}\text { César Romero } \\
\text { Calle }\end{array}$ \\
\hline 04/04/2009 & $\begin{array}{l}\text { Previo a la } \\
\text { sentencia }\end{array}$ & $\begin{array}{l}\text { Lamenta muertes de } \\
\text { La Cantuta y Barrios } \\
\text { Altos }\end{array}$ & Reportaje & $\begin{array}{l}\text { César Romero } \\
\text { Calle }\end{array}$ \\
\hline 04/04/2009 & $\begin{array}{c}\text { Previo a la } \\
\text { sentencia }\end{array}$ & En su hora final & Editorial & \\
\hline 04/04/2009 & $\begin{array}{c}\text { Previo a la } \\
\text { sentencia }\end{array}$ & $\begin{array}{l}\text { La derrota del } \\
\text { fujimorismo }\end{array}$ & $\begin{array}{l}\text { Columna de } \\
\text { opinión }\end{array}$ & $\begin{array}{l}\text { Alberto } \\
\text { Adrianzén }\end{array}$ \\
\hline 05/04/2009 & $\begin{array}{c}\text { Previo a la } \\
\text { sentencia }\end{array}$ & $\begin{array}{l}\text { Tribunal condenaría a } \\
\text { Fujimori }\end{array}$ & Reportaje & $\begin{array}{l}\text { César Romero } \\
\text { Calle }\end{array}$ \\
\hline 05/04/2009 & $\begin{array}{c}\text { Previo a la } \\
\text { sentencia }\end{array}$ & Las pruebas & $\begin{array}{l}\text { Columna de } \\
\text { opinión }\end{array}$ & $\begin{array}{l}\text { Fernando } \\
\text { Rospligiosi }\end{array}$ \\
\hline 05/04/2009 & $\begin{array}{c}\text { Previo a la } \\
\text { sentencia }\end{array}$ & $\begin{array}{l}\text { Un } 5 \text { de abril muy } \\
\text { diferente }\end{array}$ & $\begin{array}{l}\text { Columna de } \\
\text { opinión }\end{array}$ & $\begin{array}{l}\text { Augusto } \\
\text { Álvarez } \\
\text { Rodrich }\end{array}$ \\
\hline 05/04/2009 & $\begin{array}{c}\text { Previo a la } \\
\text { sentencia }\end{array}$ & La doble vara & $\begin{array}{l}\text { Columna de } \\
\text { opinión }\end{array}$ & Jorge Bruce \\
\hline 05/04/2009 & $\begin{array}{c}\text { Previo a la } \\
\text { sentencia }\end{array}$ & No sabía nada & $\begin{array}{l}\text { Columna de } \\
\text { opinión }\end{array}$ & Carlos Castro \\
\hline 05/04/2009 & $\begin{array}{c}\text { Previo a la } \\
\text { sentencia }\end{array}$ & $\begin{array}{l}\text { "Será un hito jurídico } \\
\text { mundial" }\end{array}$ & Entrevista & Inés Flores \\
\hline 05/04/2009 & $\begin{array}{c}\text { Previo a la } \\
\text { sentencia }\end{array}$ & $\begin{array}{l}\text { "La justicia es la razón } \\
\text { de nuestra lucha" }\end{array}$ & $\begin{array}{l}\text { Nota } \\
\text { informativa }\end{array}$ & $\begin{array}{l}\text { María Elena } \\
\text { Hidalgo }\end{array}$ \\
\hline $05 / 04 / 2009$ & $\begin{array}{c}\text { Previo a la } \\
\text { sentencia }\end{array}$ & $\begin{array}{l}\text { Los familiares de las } \\
\text { víctimas de Fujimori } \\
\text { realizarán una vigilia }\end{array}$ & $\begin{array}{l}\text { Nota } \\
\text { informativa }\end{array}$ & 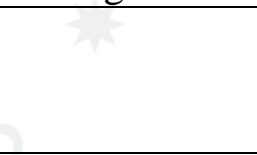 \\
\hline 05/04/2009 & $\begin{array}{c}\text { Previo a la } \\
\text { sentencia }\end{array}$ & $\begin{array}{l}\text { Fujimoristas también } \\
\text { se movilizan }\end{array}$ & $\begin{array}{l}\text { Nota } \\
\text { informativa }\end{array}$ & \\
\hline 05/04/2009 & $\begin{array}{l}\text { Previo a la } \\
\text { sentencia }\end{array}$ & $\begin{array}{l}\text { Experto argentino } \\
\text { desestima teorías de } \\
\text { defensa de Fujimori }\end{array}$ & $\begin{array}{l}\text { Nota } \\
\text { informativa }\end{array}$ & $\begin{array}{l}\text { María Elena } \\
\text { Hidalgo }\end{array}$ \\
\hline 05/04/2009 & $\begin{array}{l}\text { Previo a la } \\
\text { sentencia }\end{array}$ & $\begin{array}{l}\text { Los mejores jueces } \\
\text { sentenciarán a } \\
\text { Fujimori }\end{array}$ & $\begin{array}{l}\text { Nota } \\
\text { informativa }\end{array}$ & \\
\hline 05/04/2009 & $\begin{array}{c}\text { Previo a la } \\
\text { sentencia }\end{array}$ & $\begin{array}{l}\text { Delegación de } \\
\text { Amnistía Internacional } \\
\text { asistirá a la lectura de } \\
\text { sentencia }\end{array}$ & $\begin{array}{l}\text { Nota } \\
\text { informativa }\end{array}$ & \\
\hline 05/04/2009 & Previo a la & Otros expertos llegan & Nota & \\
\hline
\end{tabular}




\begin{tabular}{|c|c|c|c|c|}
\hline & sentencia & por juicio & informativa & \\
\hline 06/04/2009 & $\begin{array}{l}\text { Previo a la } \\
\text { sentencia }\end{array}$ & $\begin{array}{l}\text { Ahora amenazan con } \\
\text { violencia }\end{array}$ & Reportaje & $\begin{array}{l}\text { Edmundo } \\
\text { Cruz }\end{array}$ \\
\hline 06/04/2009 & $\begin{array}{c}\text { Previo a la } \\
\text { sentencia }\end{array}$ & Responsable o sonso & $\begin{array}{l}\text { Columna de } \\
\text { opinión }\end{array}$ & $\begin{array}{l}\text { Javier Diez } \\
\text { Canseco }\end{array}$ \\
\hline 06/04/2009 & $\begin{array}{l}\text { Previo a la } \\
\text { sentencia }\end{array}$ & $\begin{array}{l}\text { "La historia no se } \\
\text { puede borrar" }\end{array}$ & Entrevista & $\begin{array}{l}\text { Juan Álvarez } \\
\text { Morales }\end{array}$ \\
\hline 06/04/2009 & $\begin{array}{c}\text { Previo a la } \\
\text { sentencia }\end{array}$ & $\begin{array}{l}\text { Titular del Poder } \\
\text { Judicial, Javier Villa } \\
\text { Stein, pide respetar } \\
\text { sentencia }\end{array}$ & $\begin{array}{l}\text { Nota } \\
\text { informativa }\end{array}$ & \\
\hline 06/04/2009 & $\begin{array}{l}\text { Previo a la } \\
\text { sentencia }\end{array}$ & Justicia no es venganza & Editorial & \\
\hline 06/04/2009 & $\begin{array}{l}\text { Previo a la } \\
\text { sentencia }\end{array}$ & El móvil de todo & $\begin{array}{l}\text { Columna de } \\
\text { opinión }\end{array}$ & Carlos Reyna \\
\hline 06/04/2009 & $\begin{array}{l}\text { Previo a la } \\
\text { sentencia }\end{array}$ & $\begin{array}{l}\text { "Es razonable pensar } \\
\text { que sí tuvo control" }\end{array}$ & $\begin{array}{l}\text { Nota } \\
\text { informativa }\end{array}$ & Alonso Ramos \\
\hline 06/04/2009 & $\begin{array}{c}\text { Previo a la } \\
\text { sentencia }\end{array}$ & $\begin{array}{l}\text { 64\% considera } \\
\text { culpable a Fujimori }\end{array}$ & $\begin{array}{l}\text { Nota } \\
\text { informativa }\end{array}$ & \\
\hline 06/04/2009 & $\begin{array}{l}\text { Previo a la } \\
\text { sentencia }\end{array}$ & $\begin{array}{l}\text { "Justicia no es } \\
\text { venganza" }\end{array}$ & $\begin{array}{l}\text { Nota } \\
\text { informativa }\end{array}$ & \\
\hline 06/04/2009 & $\begin{array}{c}\text { Previo a la } \\
\text { sentencia }\end{array}$ & $\begin{array}{l}\text { Fujimori se contradijo } \\
\text { en alocución final }\end{array}$ & Nota & \\
\hline 07/04/2009 & La sentencia & $\begin{array}{l}\text { Horas decisivas para la } \\
\text { justicia }\end{array}$ & Reportaje & César Romero \\
\hline 07/04/2009 & La sentencia & $\begin{array}{l}\text { "Ud. interrumpió la } \\
\text { democracia, yo no" }\end{array}$ & $\begin{array}{l}\text { Nota } \\
\text { informativa }\end{array}$ & Inés Flores \\
\hline 07/04/2009 & La sentencia & $\begin{array}{l}\text { Expertos resaltan } \\
\text { carácter histórico y } \\
\text { limpio del juicio }\end{array}$ & $\begin{array}{l}\text { Nota } \\
\text { informativa }\end{array}$ & \\
\hline 07/04/2009 & La sentencia & Momento histórico & $\begin{array}{l}\text { Columna de } \\
\text { opinión }\end{array}$ & $\begin{array}{l}\text { Augusto } \\
\text { Álvarez } \\
\text { Rodrich }\end{array}$ \\
\hline 07/04/2009 & La sentencia & $\begin{array}{l}\text { Humala: Fujimori es } \\
\text { culpable de crímenes }\end{array}$ & $\begin{array}{l}\text { Nota } \\
\text { informativa }\end{array}$ & $+2 x^{2}$ \\
\hline 07/04/2009 & La sentencia & $\begin{array}{l}\text { Lourdes Flores invoca } \\
\text { a respetar fallo }\end{array}$ & $\begin{array}{l}\text { Nota } \\
\text { informativa }\end{array}$ & ) \\
\hline 07/04/2009 & La sentencia & $\begin{array}{l}\text { "Es momento de que } \\
\text { se haga justicia" }\end{array}$ & $\begin{array}{l}\text { Nota } \\
\text { informativa }\end{array}$ & Ana Núñez \\
\hline 07/04/2009 & La sentencia & $\begin{array}{l}\text { Seguidores de } \\
\text { Fujimori fueron } \\
\text { movilizados a la } \\
\text { Diroes }\end{array}$ & $\begin{array}{l}\text { Nota } \\
\text { informativa }\end{array}$ & \\
\hline 07/04/2009 & La sentencia & $\begin{array}{l}\text { PNP no permitirá actos } \\
\text { de violencia }\end{array}$ & $\begin{array}{l}\text { Nota } \\
\text { informativa }\end{array}$ & \\
\hline 07/04/2009 & La sentencia & Hora de la justicia & Editorial & \\
\hline 07/04/2009 & La sentencia & El juicio a Fujimori & $\begin{array}{l}\text { Columna de } \\
\text { opinión }\end{array}$ & Martín Tanaka \\
\hline $07 / 04 / 2009$ & La sentencia & Sátrapas & Columna de & Ángel Páez \\
\hline
\end{tabular}




\begin{tabular}{|c|c|c|c|c|}
\hline & & & opinión & \\
\hline 07/04/2009 & La sentencia & De mitos varios & $\begin{array}{l}\text { Columna de } \\
\text { opinión }\end{array}$ & Hugo Neira \\
\hline 08/04/2009 & La sentencia & $\begin{array}{l}\text { Hace } 10 \text { años. Los } \\
\text { condenados }\end{array}$ & $\begin{array}{l}\text { Columna de } \\
\text { opinión }\end{array}$ & $\begin{array}{l}\text { Gustavo } \\
\text { Mohme }\end{array}$ \\
\hline 08/04/2009 & La sentencia & $\begin{array}{l}\text { Diecisiete años } \\
\text { después... }\end{array}$ & Editorial & \\
\hline 08/04/2009 & La sentencia & No matarás & $\begin{array}{l}\text { Columna de } \\
\text { opinión }\end{array}$ & $\begin{array}{l}\text { Augusto } \\
\text { Álvarez } \\
\text { Rodrich }\end{array}$ \\
\hline 08/04/2009 & La sentencia & $\begin{array}{l}\text { "No tengo ningún } \\
\text { sentimiento de } \\
\text { venganza ni de } \\
\text { regodeo" }\end{array}$ & Entrevista & $\begin{array}{l}\text { María Elena } \\
\text { Hidalgo }\end{array}$ \\
\hline 08/04/2009 & La sentencia & $\begin{array}{l}\text { "Los dictadores están } \\
\text { advertidos" }\end{array}$ & Entrevista & $\begin{array}{l}\text { Pedro } \\
\text { Escribano }\end{array}$ \\
\hline 08/04/2009 & La sentencia & $\begin{array}{l}\text { Contundente e } \\
\text { irrefutable }\end{array}$ & Reportaje & César Romero \\
\hline 08/04/2009 & La sentencia & $\begin{array}{l}\text { Diecisiete años } \\
\text { después... }\end{array}$ & $\begin{array}{l}\text { Nota } \\
\text { informativa }\end{array}$ & \\
\hline $08 / 04 / 2009$ & La sentencia & $\begin{array}{l}\text { Los sólidos } \\
\text { argumentos de la Sala } \\
\text { Penal de la Suprema }\end{array}$ & $\begin{array}{l}\text { Nota } \\
\text { informativa }\end{array}$ & César Romero \\
\hline 08/04/2009 & La sentencia & $\begin{array}{l}\text { Textual, la Decisión de } \\
\text { la Sala }\end{array}$ & $\begin{array}{l}\text { Nota } \\
\text { informativa }\end{array}$ & \\
\hline 08/04/2009 & La sentencia & $\begin{array}{l}\text { Keiko aprovechó } \\
\text { sentencia para hablar } \\
\text { de su candidatura }\end{array}$ & $\begin{array}{l}\text { Nota } \\
\text { informativa }\end{array}$ & \\
\hline 08/04/2009 & La sentencia & $\begin{array}{l}\text { El fallo reconoce } \\
\text { inocencia de las } \\
\text { víctimas }\end{array}$ & $\begin{array}{l}\text { Nota } \\
\text { informativa }\end{array}$ & $\begin{array}{l}\text { María Elena } \\
\text { Castillo }\end{array}$ \\
\hline 08/04/2009 & La sentencia & $\begin{array}{l}\text { Plantón de familiares } \\
\text { de las víctimas de El } \\
\text { Santa }\end{array}$ & $\begin{array}{l}\text { Nota } \\
\text { informativa }\end{array}$ & $\begin{array}{l}\text { Lindberg } \\
\text { Cruzado y } \\
\text { Elías Navarro } \\
\end{array}$ \\
\hline 08/04/2009 & La sentencia & $\begin{array}{l}\text { Es una sentencia } \\
\text { histórica para el Perú y } \\
\text { el mundo }\end{array}$ & Reportaje & $\begin{array}{l}\text { Edmundo } \\
\text { Cruz }\end{array}$ \\
\hline 08/04/2009 & La sentencia & $\begin{array}{l}\text { Elogiaron calidad de } \\
\text { los jueces }\end{array}$ & $\begin{array}{l}\text { Nota } \\
\text { informativa }\end{array}$ & Inés Flores \\
\hline 08/04/2009 & La sentencia & $\begin{array}{l}\text { "Sentencia es un } \\
\text { ejemplo mundial" }\end{array}$ & $\begin{array}{l}\text { Nota } \\
\text { informativa }\end{array}$ & \\
\hline 08/04/2009 & La sentencia & $\begin{array}{l}\text { "Proceso judicial se } \\
\text { ajustó al debido } \\
\text { proceso" }\end{array}$ & $\begin{array}{l}\text { Nota } \\
\text { informativa }\end{array}$ & \\
\hline 08/04/2009 & La sentencia & $\begin{array}{l}\text { Víctor Delfín: "Esta es } \\
\text { una conquista del } \\
\text { pueblo peruano" }\end{array}$ & $\begin{array}{l}\text { Nota } \\
\text { informativa }\end{array}$ & \\
\hline 08/04/2009 & La sentencia & $\begin{array}{l}\text { "La verdad y la justicia } \\
\text { han triunfado" }\end{array}$ & $\begin{array}{l}\text { Nota } \\
\text { informativa }\end{array}$ & $\begin{array}{l}\text { Miguel } \\
\text { Gutiérrez }\end{array}$ \\
\hline
\end{tabular}




\begin{tabular}{|c|c|c|c|c|}
\hline 08/04/2009 & La sentencia & $\begin{array}{l}\text { Etcheverry: "La } \\
\text { condena está } \\
\text { justificada" }\end{array}$ & $\begin{array}{l}\text { Nota } \\
\text { informativa }\end{array}$ & $\begin{array}{l}\text { María Elena } \\
\text { Hidalgo }\end{array}$ \\
\hline 08/04/2009 & La sentencia & $\begin{array}{l}\text { Justicia que alivia el } \\
\text { dolor }\end{array}$ & Reportaje & \\
\hline 08/04/2009 & La sentencia & Leguía y Fujimori & $\begin{array}{l}\text { Columna de } \\
\text { opinión }\end{array}$ & $\begin{array}{l}\text { Antonio } \\
\text { Zapata }\end{array}$ \\
\hline 08/04/2009 & La sentencia & Un día después & $\begin{array}{l}\text { Columna de } \\
\text { opinión }\end{array}$ & $\begin{array}{l}\text { Nelson } \\
\text { Manrique }\end{array}$ \\
\hline 08/04/2009 & La sentencia & La prensa en el mundo & $\begin{array}{l}\text { Nota } \\
\text { informativa }\end{array}$ & \\
\hline 09/04/2009 & La sentencia & $\begin{array}{l}\text { ¿Quién necesitaba } \\
\text { Barrios Altos y } \\
\text { Cantuta? }\end{array}$ & $\begin{array}{l}\text { Columna de } \\
\text { opinión }\end{array}$ & Nicolás Lynch \\
\hline 09/04/2009 & La sentencia & $\begin{array}{l}\text { Este es el tribunal de } \\
\text { apelación }\end{array}$ & $\begin{array}{l}\text { Nota } \\
\text { informativa }\end{array}$ & César Romero \\
\hline 09/04/2009 & La sentencia & $\begin{array}{l}\text { El mundo califica } \\
\text { sentencia a Fujimori } \\
\text { como lección de } \\
\text { democracia y justicia }\end{array}$ & $\begin{array}{l}\text { Nota } \\
\text { informativa }\end{array}$ & Miluska Soko \\
\hline $09 / 04 / 2009$ & La sentencia & $\begin{array}{l}\text { Los otros delitos del } \\
\text { destacamento Colina } \\
{[\mathrm{I}]}\end{array}$ & $\begin{array}{l}\text { Nota } \\
\text { informativa }\end{array}$ & \\
\hline 09/04/2009 & La sentencia & $\begin{array}{l}\text { Fujimori debe cumplir } \\
18 \text { años de prisión } \\
\text { efectiva }\end{array}$ & $\begin{array}{l}\text { Nota } \\
\text { informativa }\end{array}$ & $\begin{array}{l}\text { María Elena } \\
\text { Castillo }\end{array}$ \\
\hline 09/04/2009 & La sentencia & $\begin{array}{l}\text { "Justicia no es igual a } \\
\text { venganza" }\end{array}$ & $\begin{array}{l}\text { Nota } \\
\text { informativa }\end{array}$ & \\
\hline 09/04/2009 & La sentencia & $\begin{array}{l}\text { Prensa peruana destacó } \\
\text { labor del tribunal y } \\
\text { justicia del fallo }\end{array}$ & $\begin{array}{l}\text { Nota } \\
\text { informativa }\end{array}$ & \\
\hline 09/04/2009 & La sentencia & $\begin{array}{l}\text { Sentencia señala que } \\
\text { Fujimori avaló las } \\
\text { acciones criminales de } \\
\text { Montesinos }\end{array}$ & Reportaje & Ángel Páez \\
\hline 09/04/2009 & La sentencia & $\begin{array}{l}\text { Fallo debe hacer } \\
\text { reflexionar a las } \\
\text { autoridades }\end{array}$ & $\begin{array}{l}\text { Nota } \\
\text { informativa }\end{array}$ & () \\
\hline 09/04/2009 & La sentencia & $\begin{array}{l}\text { "Fujimori destruyó la } \\
\text { institucionalidad de las } \\
\text { Fuerzas Armadas" }\end{array}$ & $\begin{array}{l}\text { Nota } \\
\text { informativa }\end{array}$ & \\
\hline 09/04/2009 & La sentencia & $\begin{array}{l}\text { Post-condena: ¿hay } \\
\text { oasis en ese desierto? }\end{array}$ & $\begin{array}{l}\text { Columna de } \\
\text { opinión }\end{array}$ & Mirko Lauer \\
\hline 09/04/2009 & La sentencia & $\begin{array}{l}\text { La repercusión } \\
\text { mundial }\end{array}$ & Editorial & \\
\hline 09/04/2009 & La sentencia & La vida no vale nada & $\begin{array}{l}\text { Columna de } \\
\text { opinión }\end{array}$ & $\begin{array}{l}\text { María Elena } \\
\text { Castillo }\end{array}$ \\
\hline $10 / 04 / 2009$ & La sentencia & $\begin{array}{l}\text { Procurador confía en } \\
\text { obtener una segunda }\end{array}$ & $\begin{array}{l}\text { Nota } \\
\text { informativa }\end{array}$ & César Romero \\
\hline
\end{tabular}




\begin{tabular}{|c|c|c|c|c|}
\hline & & condena para Fujimori & & \\
\hline $10 / 04 / 2009$ & La sentencia & $\begin{array}{l}\text { La sentencia de la } \\
\text { memoria }\end{array}$ & $\begin{array}{l}\text { Columna de } \\
\text { opinión }\end{array}$ & $\begin{array}{l}\text { Diego García } \\
\text { Sayán }\end{array}$ \\
\hline $10 / 04 / 2009$ & La sentencia & $\begin{array}{l}\text { "Sentencia es de una } \\
\text { gran factura y de una } \\
\text { solidez intachable" }\end{array}$ & Entrevista & $\begin{array}{l}\text { Miguel } \\
\text { Gutiérrez }\end{array}$ \\
\hline $10 / 04 / 2009$ & La sentencia & $\begin{array}{l}\text { Abogados de la parte } \\
\text { civil pidieron } \\
\text { establecer inocencia de } \\
\text { víctimas }\end{array}$ & $\begin{array}{l}\text { Nota } \\
\text { informativa }\end{array}$ & \\
\hline $10 / 04 / 2009$ & La sentencia & $\begin{array}{l}\text { Resaltan el aporte } \\
\text { periodístico en } \\
\text { histórica condena a } \\
\text { Fujimori }\end{array}$ & $\begin{array}{l}\text { Nota } \\
\text { informativa }\end{array}$ & \\
\hline $10 / 04 / 2009$ & La sentencia & $\begin{array}{l}\text { Los otros delitos del } \\
\text { destacamento Colina } \\
\text { [II] }\end{array}$ & $\begin{array}{l}\text { Nota } \\
\text { informativa }\end{array}$ & \\
\hline $10 / 04 / 2009$ & La sentencia & Neofujimoristas & Editorial & +2 \\
\hline $10 / 04 / 2009$ & La sentencia & $\begin{array}{l}\text { ¿Está probado? Sí, lo } \\
\text { está }\end{array}$ & $\begin{array}{l}\text { Columna de } \\
\text { opinión }\end{array}$ & $\begin{array}{l}\text { Sinesio López } \\
\text { Jiménez }\end{array}$ \\
\hline $11 / 04 / 2009$ & La sentencia & $\begin{array}{l}\text { Sentencia reivindica } \\
\text { también la memoria de } \\
\text { víctimas de Fujimori }\end{array}$ & $\begin{array}{l}\text { Nota } \\
\text { informativa }\end{array}$ & César Romero \\
\hline $11 / 04 / 2009$ & La sentencia & $\begin{array}{l}\text { "Caso Fujimori podría } \\
\text { servir como } \\
\text { jurisprudencia en un } \\
\text { proceso a Bush" }\end{array}$ & Entrevista & Miluska Soko \\
\hline $11 / 04 / 2009$ & La sentencia & $\begin{array}{l}\text { Los otros delitos del } \\
\text { destacamento Colina } \\
\text { [III] }\end{array}$ & $\begin{array}{l}\text { Nota } \\
\text { informativa }\end{array}$ & \\
\hline $11 / 04 / 2009$ & La sentencia & $\begin{array}{l}\text { Fujimori después de } \\
\text { Fujimori }\end{array}$ & $\begin{array}{l}\text { Columna de } \\
\text { opinión }\end{array}$ & $\begin{array}{l}\text { Juan De La } \\
\text { Puente }\end{array}$ \\
\hline $11 / 04 / 2009$ & La sentencia & $\begin{array}{l}\text { Un momento de } \\
\text { esperanza para salir del } \\
\text { gueto }\end{array}$ & $\begin{array}{l}\text { Columna de } \\
\text { opinión }\end{array}$ & $\begin{array}{l}\text { Alberto } \\
\text { Adrianzén }\end{array}$ \\
\hline $11 / 04 / 2009$ & La sentencia & La regresión & $\begin{array}{l}\text { Columna de } \\
\text { opinión }\end{array}$ & Mirko Lauer \\
\hline $12 / 04 / 2009$ & La sentencia & $\begin{array}{l}\text { Si Fujimori derrotó a } \\
\text { Sendero, ¿por qué lo } \\
\text { seguimos } \\
\text { combatiendo? }\end{array}$ & $\begin{array}{l}\text { Columna de } \\
\text { opinión }\end{array}$ & Mirko Lauer \\
\hline $12 / 04 / 2009$ & La sentencia & CVR II & $\begin{array}{l}\text { Columna de } \\
\text { opinión }\end{array}$ & Jorge Bruce \\
\hline $12 / 04 / 2009$ & La sentencia & $\begin{array}{l}\text { "Investigación de la } \\
\text { prensa fue decisiva en } \\
\text { sentencia a Fujimori", }\end{array}$ & Entrevista & Inés Flores \\
\hline $12 / 04 / 2009$ & La sentencia & $\begin{array}{l}\text { Las pruebas que valoró } \\
\text { el tribunal }\end{array}$ & Reportaje & César Romero \\
\hline $12 / 04 / 2009$ & La sentencia & Existencia del grupo & Nota & César Romero \\
\hline
\end{tabular}




\begin{tabular}{|c|c|c|c|c|}
\hline & & $\begin{array}{l}\text { Colina demuestra la } \\
\text { autoría mediata }\end{array}$ & informativa & \\
\hline $12 / 04 / 2009$ & La sentencia & Reconocimiento & $\begin{array}{l}\text { Columna de } \\
\text { opinión }\end{array}$ & Carlos Castro \\
\hline $13 / 04 / 2009$ & La sentencia & Abogado del diablo & $\begin{array}{l}\text { Columna de } \\
\text { opinión }\end{array}$ & $\begin{array}{l}\text { Augusto } \\
\text { Álvarez } \\
\text { Rodrich }\end{array}$ \\
\hline $13 / 04 / 2009$ & La sentencia & Con el juicio perdido & $\begin{array}{l}\text { Columna de } \\
\text { opinión }\end{array}$ & Carlos Reyna \\
\hline 13/04/2009 & La sentencia & El terror de Fujimori & Editorial & \\
\hline $14 / 04 / 2009$ & La sentencia & $\begin{array}{l}\text { La condena de } \\
\text { Fujimori }\end{array}$ & $\begin{array}{l}\text { Columna de } \\
\text { opinión }\end{array}$ & Martín Tanaka \\
\hline $14 / 04 / 2009$ & La sentencia & Cínicos & $\begin{array}{l}\text { Columna de } \\
\text { opinión }\end{array}$ & Ángel Páez \\
\hline 02/01/2010 & $\begin{array}{l}\text { La sentencia } \\
\text { (ratificación) }\end{array}$ & $\begin{array}{l}\text { Tribunal alista } \\
\text { sentencia a Fujimori }\end{array}$ & $\begin{array}{l}\text { Nota } \\
\text { informativa }\end{array}$ & \\
\hline 03/01/2010 & $\begin{array}{l}\text { La sentencia } \\
\text { (ratificación) }\end{array}$ & $\begin{array}{l}\text { Confirman condena de } \\
25 \text { años }\end{array}$ & Reportaje & César Romero \\
\hline 04/01/2010 & $\begin{array}{l}\text { La sentencia } \\
\text { (ratificación) }\end{array}$ & $\begin{array}{l}\text { Fujimori no puede ser } \\
\text { indultado }\end{array}$ & Reportaje & César Romero \\
\hline 04/01/2010 & $\begin{array}{l}\text { La sentencia } \\
\text { (ratificación) }\end{array}$ & $\begin{array}{l}8 \text { claves de la } \\
\text { sentencia a Fujimori }\end{array}$ & $\begin{array}{l}\text { Nota } \\
\text { informativa }\end{array}$ & \\
\hline 04/01/2010 & $\begin{array}{l}\text { La sentencia } \\
\text { (ratificación) }\end{array}$ & $\begin{array}{l}\text { Deben resolverse casos } \\
\text { pendientes }\end{array}$ & $\begin{array}{l}\text { Nota } \\
\text { informativa }\end{array}$ & $\begin{array}{l}\text { Francesca } \\
\text { García }\end{array}$ \\
\hline 04/01/2010 & $\begin{array}{l}\text { La sentencia } \\
\text { (ratificación) }\end{array}$ & $\begin{array}{l}\text { Nakasaki evalúa acudir } \\
\text { a TC }\end{array}$ & $\begin{array}{l}\text { Nota } \\
\text { informativa }\end{array}$ & \\
\hline 04/01/2010 & $\begin{array}{l}\text { La sentencia } \\
\text { (ratificación) }\end{array}$ & $\begin{array}{l}\text { "Proceso penal fue } \\
\text { imparcial" }\end{array}$ & $\begin{array}{l}\text { Nota } \\
\text { informativa }\end{array}$ & \\
\hline 04/01/2010 & $\begin{array}{l}\text { La sentencia } \\
\text { (ratificación) }\end{array}$ & $\begin{array}{l}\text { "Fue un proceso } \\
\text { intachable" }\end{array}$ & $\begin{array}{l}\text { Nota } \\
\text { informativa }\end{array}$ & \\
\hline 04/01/2010 & $\begin{array}{l}\text { La sentencia } \\
\text { (ratificación) }\end{array}$ & $\begin{array}{l}\text { "Juicio a Fujimori hizo } \\
\text { historia" }\end{array}$ & $\begin{array}{l}\text { Nota } \\
\text { informativa }\end{array}$ & \\
\hline 04/01/2010 & $\begin{array}{l}\text { La sentencia } \\
\text { (ratificación) }\end{array}$ & Ensayo de orquesta & $\begin{array}{l}\text { Columna de } \\
\text { opinión }\end{array}$ & $\begin{array}{l}\text { Augusto } \\
\text { Álvarez } \\
\text { Rodrich }\end{array}$ \\
\hline 04/01/2010 & $\begin{array}{l}\text { La sentencia } \\
\text { (ratificación) }\end{array}$ & $\begin{array}{l}\text { Fujimori: se hizo } \\
\text { justicia }\end{array}$ & Editorial & 0 \\
\hline 05/01/2010 & $\begin{array}{l}\text { La sentencia } \\
\text { (ratificación) }\end{array}$ & $\begin{array}{l}\text { TC no puede liberar a } \\
\text { Fujimori }\end{array}$ & Reportaje & César Romero \\
\hline
\end{tabular}

\section{ANEXO 4: Lista total de publicaciones de El Comercio}

\begin{tabular}{|c|c|c|c|c|}
\hline Fecha & Hito & Titular & Tipo de nota & Firma \\
\hline 05/04/2009 & $\begin{array}{c}\text { Previo a la } \\
\text { sentencia }\end{array}$ & $\begin{array}{l}\text { La otra memoria y la } \\
\text { otra historia }\end{array}$ & $\begin{array}{l}\text { Columna de } \\
\text { opinión }\end{array}$ & $\begin{array}{l}\text { Juan Paredes } \\
\text { Castro }\end{array}$ \\
\hline 05/04/2009 & $\begin{array}{l}\text { Previo a la } \\
\text { sentencia }\end{array}$ & $\begin{array}{l}\text { Un proceso ejemplar } \\
\text { en democracia y por } \\
\text { DDHH }\end{array}$ & Editorial & \\
\hline $05 / 04 / 2009$ & Previo a la & La verdad en la & Columna de & Francisco Miró \\
\hline
\end{tabular}




\begin{tabular}{|c|c|c|c|c|}
\hline & sentencia & política & opinión & $\begin{array}{l}\text { Quesada } \\
\text { (Director) }\end{array}$ \\
\hline 06/04/2009 & $\begin{array}{c}\text { Previo a la } \\
\text { sentencia }\end{array}$ & $\begin{array}{l}\text { Especialistas elogian } \\
\text { desarrollo del juicio }\end{array}$ & $\begin{array}{l}\text { Nota } \\
\text { informativa }\end{array}$ & $\begin{array}{l}\text { Gino Piaggio } \\
\text { Valdez }\end{array}$ \\
\hline 06/04/2009 & $\begin{array}{l}\text { Previo a la } \\
\text { sentencia }\end{array}$ & $\begin{array}{l}\text { Titular del Poder } \\
\text { Judicial invoca a } \\
\text { respetar el fallo de } \\
\text { mañana }\end{array}$ & $\begin{array}{l}\text { Nota } \\
\text { informativa }\end{array}$ & \\
\hline 06/04/2009 & $\begin{array}{c}\text { Previo a la } \\
\text { sentencia }\end{array}$ & ¡Re-fres-car! & $\begin{array}{l}\text { Columna de } \\
\text { opinión }\end{array}$ & $\begin{array}{l}\text { Luis Solari de } \\
\text { la Fuente }\end{array}$ \\
\hline 07/04/2009 & La sentencia & $\begin{array}{l}\text { Los actos fallidos de } \\
\text { Alberto Fujimori }\end{array}$ & $\begin{array}{l}\text { Columna de } \\
\text { opinión }\end{array}$ & $\begin{array}{l}\text { Enrique } \\
\text { Bernales } \\
\end{array}$ \\
\hline 07/04/2009 & La sentencia & $\begin{array}{l}\text { ¿En qué justicia y } \\
\text { democracia cree } \\
\text { Keiko Fujimori? }\end{array}$ & $\begin{array}{l}\text { Columna de } \\
\text { opinión }\end{array}$ & $\begin{array}{l}\text { Juan Paredes } \\
\text { Castro }\end{array}$ \\
\hline 07/04/2009 & La sentencia & $\begin{array}{l}\text { Todos debemos acatar } \\
\text { el fallo de la justicia }\end{array}$ & Editorial & \\
\hline 07/04/2009 & La sentencia & $\begin{array}{l}\text { Posibilidad de } \\
\text { condena agista a los } \\
\text { fujimoristas }\end{array}$ & $\begin{array}{l}\text { Nota } \\
\text { informativa }\end{array}$ & Mario Mejía \\
\hline 08/04/2009 & La sentencia & $\begin{array}{l}\text { Organizaciones } \\
\text { internacionales de } \\
\text { acuerdo con justicia } \\
\text { peruana }\end{array}$ & $\begin{array}{l}\text { Nota } \\
\text { informativa }\end{array}$ & \\
\hline 08/04/2009 & La sentencia & $\begin{array}{l}\text { El autócrata es } \\
\text { culpable }\end{array}$ & $\begin{array}{l}\text { Columna de } \\
\text { opinión }\end{array}$ & Henry Pease \\
\hline 08/04/2009 & La sentencia & $\begin{array}{l}\text { El fin de la } \\
\text { arbitrariedad }\end{array}$ & $\begin{array}{l}\text { Columna de } \\
\text { opinión }\end{array}$ & $\begin{array}{l}\text { Francisco Miró } \\
\text { Quesada } \\
\text { (Director) }\end{array}$ \\
\hline 08/04/2009 & La sentencia & $\begin{array}{l}\text { ¡Oh, democracia, } \\
\text { cuantos crímenes se } \\
\text { cometen en tu } \\
\text { nombre! }\end{array}$ & $\begin{array}{l}\text { Columna de } \\
\text { opinión }\end{array}$ & Martha Chávez \\
\hline 08/04/2009 & La sentencia & $\begin{array}{l}\text { Los dictadores no son } \\
\text { invulnerables }\end{array}$ & $\begin{array}{l}\text { Columna de } \\
\text { opinión }\end{array}$ & $\begin{array}{l}\text { Jorge } \\
\text { Avendaño }\end{array}$ \\
\hline 08/04/2009 & La sentencia & $\begin{array}{l}\text { Ex contrincantes } \\
\text { políticos aplauden } \\
\text { sentencia }\end{array}$ & $\begin{array}{l}\text { Nota } \\
\text { informativa }\end{array}$ & \\
\hline 08/04/2009 & La sentencia & $\begin{array}{l}\text { Una sentencia justa y } \\
\text { severa que debe } \\
\text { acatarse }\end{array}$ & Editorial & \\
\hline 08/04/2009 & La sentencia & $\begin{array}{l}\text { El fallo desde todos } \\
\text { los ángulos }\end{array}$ & Reportaje & \\
\hline 08/04/2009 & La sentencia & $\begin{array}{l}\text { La sala falló: } 25 \text { años } \\
\text { de cárcel }\end{array}$ & Reportaje & Mario Mejía \\
\hline 08/04/2009 & La sentencia & $\begin{array}{l}\text { Beneficios, indulto, } \\
\text { los otros procesos }\end{array}$ & $\begin{array}{l}\text { Nota } \\
\text { informativa }\end{array}$ & \\
\hline 08/04/2009 & La sentencia & $\begin{array}{l}\text { Simon y Del Castillo } \\
\text { destacan }\end{array}$ & $\begin{array}{l}\text { Nota } \\
\text { informativa }\end{array}$ & \\
\hline
\end{tabular}




\begin{tabular}{|c|c|c|c|c|}
\hline & & $\begin{array}{l}\text { independencia de los } \\
\text { jueces }\end{array}$ & & \\
\hline 08/04/2009 & La sentencia & $\begin{array}{l}\text { Resolución } \\
\text { contundente e } \\
\text { irrefutable }\end{array}$ & Reportaje & Óscar Castilla \\
\hline 08/04/2009 & La sentencia & $\begin{array}{l}\text { Exaltada reacción de } \\
\text { los fujimoristas }\end{array}$ & Reportaje & \\
\hline 08/04/2009 & La sentencia & $\begin{array}{l}\text { Diez preguntas para } \\
\text { frenar la intolerancia }\end{array}$ & $\begin{array}{l}\text { Columna de } \\
\text { opinión }\end{array}$ & $\begin{array}{l}\text { Juan Paredes } \\
\text { Castro }\end{array}$ \\
\hline 09/04/2009 & La sentencia & $\begin{array}{l}\text { La figura jurídica que } \\
\text { fue clave }\end{array}$ & $\begin{array}{l}\text { Nota } \\
\text { informativa }\end{array}$ & \\
\hline 09/04/2009 & La sentencia & Un proceso histórico & $\begin{array}{l}\text { Columna de } \\
\text { opinión }\end{array}$ & Beatriz Boza \\
\hline 09/04/2009 & La sentencia & Es injusto & $\begin{array}{l}\text { Columna de } \\
\text { opinión }\end{array}$ & $\begin{array}{l}\text { Jaime de } \\
\text { Althaus }\end{array}$ \\
\hline 09/04/2009 & La sentencia & El juicio pendiente & $\begin{array}{l}\text { Columna de } \\
\text { opinión }\end{array}$ & $\begin{array}{l}\text { Fernando } \\
\text { Vivas }\end{array}$ \\
\hline 09/04/2009 & La sentencia & $\begin{array}{l}\text { Los periódicos del } \\
\text { mundo destacaron } \\
\text { ayer la noticia }\end{array}$ & $\begin{array}{l}\text { Nota } \\
\text { informativa }\end{array}$ & \\
\hline 09/04/2009 & La sentencia & $\begin{array}{l}\text { Sacándole jugo } \\
\text { electoral al fallo }\end{array}$ & Reportaje & $\begin{array}{l}\text { Debora Dongo } \\
\text { - Soria y } \\
\text { Gerardo } \\
\text { Caballero } \\
\end{array}$ \\
\hline 09/04/2009 & La sentencia & Más allá del proceso & $\begin{array}{l}\text { Columna de } \\
\text { opinión }\end{array}$ & $\begin{array}{l}\text { Alonso Núñez } \\
\text { del Prado }\end{array}$ \\
\hline 09/04/2009 & La sentencia & $\begin{array}{l}\text { ¿El fujimorismo se } \\
\text { vuelve contra su } \\
\text { propio líder? }\end{array}$ & $\begin{array}{l}\text { Columna de } \\
\text { opinión }\end{array}$ & $\begin{array}{l}\text { Juan Paredes } \\
\text { Castro }\end{array}$ \\
\hline $12 / 04 / 2009$ & La sentencia & $\begin{array}{l}\text { Buscando la paja en } \\
\text { ojo ajeno }\end{array}$ & $\begin{array}{l}\text { Columna de } \\
\text { opinión }\end{array}$ & $\begin{array}{l}\text { Juan Paredes } \\
\text { Castro }\end{array}$ \\
\hline $12 / 04 / 2009$ & La sentencia & $\begin{array}{l}\text { Del banquillo hasta la } \\
\text { sentencia }\end{array}$ & Crónica & $\begin{array}{l}\text { Gino Piaggio } \\
\text { Valdez }\end{array}$ \\
\hline $12 / 04 / 2009$ & La sentencia & $\begin{array}{l}\text { "El indulto sería } \\
\text { inaceptable" }\end{array}$ & Entrevista & 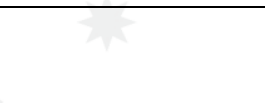 \\
\hline 13/04/2009 & La sentencia & $\begin{array}{l}\text { Fujimori y la } \\
\text { autoestima nacional }\end{array}$ & $\begin{array}{l}\text { Columna de } \\
\text { opinión }\end{array}$ & $\begin{array}{l}\text { Fernando } \\
\text { Berckemeyer }\end{array}$ \\
\hline $13 / 04 / 2009$ & La sentencia & $\begin{array}{l}\text { Tipifican delitos de } \\
\text { lesa humanidad en } \\
\text { código }\end{array}$ & $\begin{array}{l}\text { Nota } \\
\text { informativa }\end{array}$ & \\
\hline $13 / 04 / 2009$ & La sentencia & La dinastía Fujimori & $\begin{array}{l}\text { Columna de } \\
\text { opinión }\end{array}$ & $\begin{array}{l}\text { Abelardo } \\
\text { Sánchez }\end{array}$ \\
\hline 04/01/2010 & $\begin{array}{l}\text { La sentencia } \\
\text { (ratificación) }\end{array}$ & $\begin{array}{l}\text { Cumplirá su condena } \\
\text { en la Diroes }\end{array}$ & $\begin{array}{l}\text { Nota } \\
\text { informativa }\end{array}$ & \\
\hline 04/01/2010 & $\begin{array}{l}\text { La sentencia } \\
\text { (ratificación) }\end{array}$ & $\begin{array}{l}\text { Fujimori no podrá ser } \\
\text { indultado }\end{array}$ & $\begin{array}{l}\text { Nota } \\
\text { informativa }\end{array}$ & Martín León \\
\hline 05/01/2010 & $\begin{array}{l}\text { La sentencia } \\
\text { (ratificación) }\end{array}$ & Una decisión histórica & $\begin{array}{l}\text { Columna de } \\
\text { opinión }\end{array}$ & $\begin{array}{l}\text { Ronald } \\
\text { Gamarra }\end{array}$ \\
\hline 05/01/2010 & La sentencia & El final de una era & Columna de & Cesar \\
\hline
\end{tabular}




\begin{tabular}{|c|c|c|c|c|}
\hline & (ratificación) & & opinión & Azabache \\
\hline 05/01/2010 & $\begin{array}{l}\text { La sentencia } \\
\text { (ratificación) }\end{array}$ & $\begin{array}{l}\text { Caso Fujimori: se } \\
\text { ratifica una condena } \\
\text { ejemplar }\end{array}$ & Editorial & \\
\hline 05/01/2010 & $\begin{array}{l}\text { La sentencia } \\
\text { (ratificación) }\end{array}$ & $\begin{array}{l}\text { Todos concuerdan en } \\
\text { que el proceso está } \\
\text { totalmente cerrado }\end{array}$ & $\begin{array}{l}\text { Nota } \\
\text { informativa }\end{array}$ & \\
\hline 05/01/2010 & $\begin{array}{l}\text { La sentencia } \\
\text { (ratificación) }\end{array}$ & $\begin{array}{l}\text { El Tribunal } \\
\text { Constitucional no es } \\
\text { una nueva instancia } \\
\text { para revisar sentencia } \\
\text { de } 25 \text { años }\end{array}$ & $\begin{array}{l}\text { Nota } \\
\text { informativa }\end{array}$ & \\
\hline 05/01/2010 & $\begin{array}{l}\text { La sentencia } \\
\text { (ratificación) }\end{array}$ & $\begin{array}{l}\text { Inkarrí } \\
\text { fujimontesinista }\end{array}$ & $\begin{array}{l}\text { Columna de } \\
\text { opinión }\end{array}$ & $\begin{array}{l}\text { Fernando } \\
\text { Vivas }\end{array}$ \\
\hline $10 / 01 / 2010$ & $\begin{array}{l}\text { La sentencia } \\
\text { (ratificación) }\end{array}$ & $\begin{array}{l}\text { De investigadores e } \\
\text { investigados }\end{array}$ & Crónica & \\
\hline
\end{tabular}

ANEXO 5: Modelo de análisis de notas informativas

\begin{tabular}{|c|c|c|c|c|c|}
\hline Medio & Fecha & $\begin{array}{c}\text { Número } \\
\text { de fuentes }\end{array}$ & $\begin{array}{c}\text { Tipos de } \\
\text { fuentes }\end{array}$ & $\begin{array}{c}\text { Atribuciones } \\
\text { a actores }\end{array}$ & Contextualización \\
\hline & & & & & \\
\hline & & & & & \\
\hline
\end{tabular}

ANEXO 6: Modelo de análisis de editoriales

\begin{tabular}{|l|l|l|l|c|c|c|}
\hline Fecha & Título & $\begin{array}{c}\text { Tesis } \\
\text { (RESUMEN) }\end{array}$ & $\begin{array}{c}\text { Posición } \\
\text { frente al } \\
\text { tema }\end{array}$ & $\begin{array}{c}\text { Juicios } \\
\text { sobre } \\
\text { actores } \\
\text { (fujimoristas } \\
\text { y familiares } \\
\text { de víctimas) }\end{array}$ & $\begin{array}{c}\text { Frases y } \\
\text { referencias } \\
\text { directas a } \\
\text { actores }\end{array}$ & $\begin{array}{c}\text { Propuesta } \\
\text { (CONCLUSIÓN) }\end{array}$ \\
\hline & & & & & & \\
\hline
\end{tabular}

\section{ANEXO 7: Entrevista a Gisela Ortiz}

Fecha: 10/06/2015

La República y El Comercio dedicaron varias portadas a la sentencia, ¿a qué cree que se deba esto? ¿qué relevancia tiene para ustedes? 
El juicio es histórico, es la primera vez que un ex presidente es juzgado por derechos humanos. Somos un país que se ha caracterizado más bien por la impunidad y eso ha hecho que el caso tenga una gran cobertura y principalmente estos 2 periódicos, que son los más importantes a nivel nacional, han estado informando y han estado pendientes del tema. Lo otro es también porque es un presidente que estaba siendo juzgado por violación a los derechos humanos y en nuestro país, donde tenemos altísimos índices de violaciones a los derechos humanos, nunca se ha llegado a juzgar a un expresidente pese a las responsabilidades políticas. A Belaunde o Alan García nunca se les juzgó por estos delitos, creo que ahí radica fundamentalmente la importancia para la atención de los medios de comunicación. Ahora como familiares creemos que sí es fundamental porque gran parte de lo que se logra en la justicia en nuestro país tiene que ver con la vigilancia ciudadana y no solo la ejercen los familiares, desde su derecho a que se haga justicia, desde una acción pública, sino la que ejercen también los medios de comunicación. Después de la sentencia de Fujimori, y te lo digo como un tema más de contexto, se han dado muchas sentencias por violaciones a los derechos humanos, no en importancia como la de Fujimori, sino a otros actores, y la mayoría de ellas, cerca de un $70 \%$, han sido absolutorias y son procesos que no han tenido el acompañamiento de ningún medio de comunicación. Con esto quiero demostrar que muchas veces los jueces fallan no solo en función al caso, a lo que dice la ley, sino en función de la presión pública, por eso para nosotros como familiares fue importante la atención que los medios brindaron.

\section{¿Se dio verdadera importancia al tema? ¿por qué?}

Sí, más allá del enfoque. Por ejemplo, no estoy de acuerdo cuando a Fujimori se le trata con mucho respeto, el expresidente o presidente, eso más bien debería avergonzarnos a todos los peruanos. Primero porque fuimos nosotros quienes lo elegimos y lo pusimos ahí, y segundo porque siendo un expresidente se convirtió en un delincuente, sí me molesta. Pero, en general, sí, satisfecha con esa cobertura.

\section{Cuando leyó que en los medios resaltaban que sus familiares no eran terroristas,} ¿cuál fue su impresión? ¿Cómo se sintieron? ¿Fue importante leerlo en los diarios?

Fue una reparación. Primero, una satisfacción personal porque nosotros conocemos a nuestros familiares, sabemos quiénes han sido, qué cosas hacían, sabemos el esfuerzo 
que ha significado para mi hermano y para los demás muchachos que eran todos de estratos muy humildes llegar a la universidad, entonces tiene una importancia porque estamos hablando de la dignidad que tienen como personas. El que se limpie de alguna manera esta imagen que fue construida por Fujimori, Montesinos y toda la prensa que era servil a la dictadura, no solo realmente nos dignifica como familiares sino nos repara simbólicamente. Que eso esté en una portada de un medio de comunicación no es un mensaje solo para la familia, quienes vamos a ir a escuchar la sentencia, es un mensaje para la opinión pública y creo que es importante porque en nuestro país tenemos la mala costumbre también de difamar y son los medios de comunicación los que principalmente acusan sin ningún tipo de pruebas porque los escuchas, porque alguien lo dijo.

\section{¿Ayudó a dignificar la memoria de sus familiares? ¿a la justicia?}

Sí, así es. Para mí es fundamental que hayan recogido esta parte que no tiene que ver necesariamente con la condena, pero el acto simbólico que significa también una sentencia devuelve la dignidad a las víctimas.

\section{La República no dudó en referirse como ex dictador o sátrapa a Fujimori, y El} Comercio aseguró que este secuestró y asesinó con alevosía, ¿cómo perciben esto?

Creo que a veces nos perdemos en adjetivos y se pierde el objetivo fundamental de la información. Lo concreto es que Fujimori fue sentenciado por crímenes y la responsabilidad que tuvo como autor mediato en crímenes de violaciones a los derechos humanos, que son gravísimos, es casi un nivel de complicidad, es permitir que todos esos hechos se den. De por sí el hecho es grave, pero, claro, cuando se usan calificativos lo que más afianza es la posición política de cada quien. La República ha sido desde siempre un periódico de centro izquierda y muy contrario a la política de Fujimori desde el inicio. Uno de los pocos periódicos que ha estado convencido de que los 10 años, casi 11, que se quedó Fujimori fue una dictadura, y yo coincido con esa posición, yo he sido parte de esa época y soy consciente de que él no solamente se deshizo del congreso como un poder que tiene la capacidad de investigar, de supervisar lo que hace el Poder Legislativo, sino también deshizo el Poder Judicial, intervino para poner jueces a nombre (...) es una dictadura y si a eso le sumas el control de los medios de comunicación que de alguna manera tienen un poder para denunciar, informar, concientizar, estaba todo copado. Coincido con esta posición de que fue una dictadura, 
pero creo que cuando se sobrecalifica, ex dictador, sátrapa, japonés, ratero y todo lo demás, se pierde la esencia de la información. Pero lo que dice La República y lo que decía El Comercio en esa época refleja más bien su posición sobre lo que significó el régimen de Fujimori.

\section{¿Deja claro quiénes fueron las víctimas y quiénes los victimarios?}

En esa época sí porque, como te digo, toda esa construcción de que las víctimas de Cantuta eran terroristas fue una construcción que la hizo el fujimorismo, y que lo sigue haciendo hasta ahora cada vez que un fujimorista habla de nuestros familiares. Pero en ese contexto de juicio, además el juicio demostró de alguna manera quienes eran las víctimas y quienes eran los victimarios, estuvo clarísima la información que los medios de comunicación hicieron.

\section{Sin embargo, la presencia de los familiares de las víctimas no es igual en ambos medios, ¿a qué cree que se deba esto?}

A lo largo de estos más de 20 años que tengo como deudo, nosotros podemos reconocer que algunos medios fueron nuestros aliados y ahí está La República desde el inicio. En 1992, después de que secuestran a nuestros familiares en julio, nosotros organizamos con la universidad y el rector, varias conferencias de prensa y el único medio que venía era La República. No venía nadie más, alguna vez Radio Cora, pero nadie más. El Comercio nunca vino ni los medios televisados, no venía nadie. Entonces tiene que ver con una posición política del medio de comunicación, el diario La República desde siempre ha sido un periódico que ha informado sobre violaciones a los derechos humanos, tiene sus víctimas también, dentro de los periodistas que murieron en Uchuraccay, además ha recogido la voz de los familiares que somos parte de la justicia. Ha habido otros medios que no lo han hecho o no lo han hecho lo suficiente, El Comercio por ejemplo que cubre la noticia y no necesariamente recoge la posición y la opinión de los familiares. Y ha habido otros como Radio Programas que, en 22 años, si me ha entrevistado dos veces han de ser suficientes y hablo de épocas en que el caso La Cantuta ha estado en picos de información, cuando se formó la comisión en el congreso, cuando se encontraron las llaves, cuando se encontraron los cuerpos, cuando se extraditó a Fujimori. Ha habido picos y nunca nos han entrevistado como familiares, tiene que ver mucho con la posición del medio y con también la validez y la importancia que le dé al testimonio de familiares. 


\section{¿Cuál es la relevancia de sus testimonios?}

Es fundamental porque nosotros somos parte de esta historia. Nosotros somos la voz de las víctimas. Nuestros familiares están muertos, alguien tiene que hablar por ellos. La familia recoge esa voz y así como se recoge la voz de Keiko Fujimori, de Kenji, que son los hijos de Fujimori, del abogado de Fujimori, de doctor Aguinaga que es su médico y una fila más de fujimoristas, también tienen que contrapesar la información y preguntarle a la familia cómo le afecta, qué opina, cómo piensa, cómo se siente y te lo digo porque este hecho no solamente lo hemos visto acá. En época de extradición cuando estábamos en Chile, los periódicos, como El Mercurio, cada vez que informaban sobre la extradición y Fujimori lo hacían desde el punto de vista de la hija de Fujimori, de la familia Fujimori y nunca de nosotros hasta que un día fuimos a la redacción y les dijimos: bueno, nosotros también somos parte de la historia, pregúntennos, muestren quienes son las víctimas.

\section{¿Cómo ayuda a narrar el pasado?}

Mucho de lo que se escribe y se dice, tiene que ver con los hechos, que no los vas a poder cambiar, son reales, tienen pruebas y eso se construye en base a la información que tienen los familiares. Nos pueden no creer, es otra historia, es otro tema. Pueden buscar otras fuentes de información para corroborar lo que se está diciendo, pero tienes la obligación de preguntar y eso es lo que algunos medios no han hecho.

\section{Y las voces fujimoristas, ¿cree que es importante darles voz pese a que niegan la memoria de sus familiares?}

Realmente a mí me indigna que en nuestro país la gente sea tan irresponsable, tan irrespetuosa del dolor del otro. Me enerva, me da tanta rabia porque es gente que no solo opina, distinto es que yo pueda decir que estoy en contra de esa sentencia a Fujimori porque me parece injusta, sino que difama y es lo que han hecho durante todo este tiempo. No solamente contra las víctimas, no solamente contra las 10 personas en Cantuta, o contra los de Barrios Altos, sino también contra nosotros, sus familiares y contra los organismos de derechos humanos que nos han apoyado y defendido. Te difaman y lo peor es que no pasa nada. Yo he sufrido varios de los agravios de Martha Chávez y alguna vez he mandado cartas pidiendo rectificación y no pasa nada. Hay un nivel de irresponsabilidad personal, de ella, pero hay un nivel de complicidad también porque el medio de comunicación que la está entrevistando tiene la obligación de 
repreguntarle. Más allá de su opinión, hay hechos históricos, hay una sentencia judicial que ha sido ratificada por la Corte Suprema donde habla de la inocencia de nuestros familiares, de la responsabilidad de Colina, y esa es una verdad jurídica. No pueden pasar 5 años, 10 años y seguimos negando que Fujimori sea responsable de estos crímenes. Eso ya no lo decimos nosotros, lo dice un tribunal de justicia que ha tenido sus etapas para ratificar una condena y son hechos históricos para nuestro país. Ahora mismo vamos a entrar a la campaña electoral para el 2016 y seguro Keiko va a ser candidata y vamos a empezar otra vez a remover todo y a oír que Fujimori fue injustamente condenado. Realmente a mí, me genera alguna serie de sentimientos y sensaciones de desprotección porque seguimos siendo ciudadanos peruanos también igual que cualquier otro fujimorista pero no tienes un sistema que te defienda, no tienes un estado que prohíba este tipo de cosas, no tienes un fiscal que denuncie por difamación a estas personas, no tienes a un medio de comunicación que rebata lo que te están diciendo, estás como solito.

\section{¿Cómo afecta a la memoria de lo ocurrido?}

Terriblemente porque intenta tergiversar todo lo ocurrido. Son innegables los crímenes de Sendero Luminoso y el MRTA, ninguna persona puede dejar de rechazarlos y de decir que fueron lo más terrible que nos ha pasado, hay la otra parte de la historia, también de aquellos crímenes que se cometieron por parte de militares en las zonas de conflicto o los que se cometieron por estos escuadrones de la muerte entre ellos el grupo Colina, son hechos reales y sobre ellos hay que construir la historia y la memoria del país. Porque ¿qué pasa cuando los ocultamos, cuando solamente hablamos de los crímenes de Sendero o que las víctimas son culpables porque eran terroristas? Estás negando una parte de la historia y estás otra vez atropellando la dignidad de las víctimas. Pero, por otro lado, estás corriendo el riesgo de que todo vuelva a pasar. No hemos tenido la capacidad de pensar un poco en lo que ocurrió, sacar lecciones, aprender y corregir, darnos cuenta que esa no es la solución. Estamos corriendo el riesgo de ocultar lo que ya vivimos para volver a cometer los mismos errores. Por otro lado, jóvenes desinformados, salvo alguno que tenga interés personal en querer saber de estos temas y va a investigar tal vez va a descubrir lo que realmente ha ocurrido pero si no la mayoría se deja llevar por lo que aparece en los medios de comunicación y quienes tienen más tribuna en estos medios son los mismos fujimoristas que fueron cómplices de esta dictadura, que supieron de estos crímenes y nunca denunciaron y que 
más bien avalaron leyes de amnistía y ahora son como los voceros de la historia de nuestro país. Están mal formando a la opinión pública.

\section{¿Y la contextualización?}

El Comercio alguna vez sacó un especial, no de manera física sino en su página web, fue como una especie de infografía para la época de la sentencia sobre la época de Fujimori, del golpe de estado demás. Intentó recrear el contexto general de cómo ocurrieron estos crímenes. Si bien son hechos históricos sobre los cuales hay que informar y darles algún contexto, cuánta importancia le pueden dar a las víctimas, otra vez la mirada de los medios, el enfoque si son las víctimas o la obligación de tener que hablar de este hecho porque es un hecho que no se puede ocultar. Ahí radica si le vas a preguntar al familiar y vas a hablar de quienes eran las víctimas, si los vas a mencionar, si tienen nombres o apellidos o son las estadísticas, los números, entonces tiene que ver con esa mirada que marca las políticas de los medios y hay una marcada diferencia entre lo que hace La República y El Comercio. En La República siempre vas a leer, al menos, el nombre de alguno de los familiares o volver a recordar quienes eran las víctimas o volver al hecho del 18 de julio, cosas que te vuelven a recordar que estamos hablando de personas, que estamos hablando de familiares.

En ambos medios se usan antecedentes para narrar el caso, ¿cómo cree que los medios relatan a aquella noche? ¿cree que aportan al conocimiento del caso?

No contaron bien porque el antecedente siempre parte desde lo de Tarata porque es la acusación que Montesinos creó para lo de Cantuta y que luego se filtró en los medios de comunicación. Cuando nadie sabía, digo de los familiares, que había ocurrido con nuestros familiares, El Comercio, por ejemplo, hablo de setiembre del 92, sacó una nota donde decía que estudiantes de La Cantuta eran responsables de Taranta, ¿quién más sabía eso? Nadie, seguían desaparecidos. Eso no había salido en ninguna información, en ningún sitio. Yo recuerdo claramente que una noche, tal vez agosto del año 92, en el canal 5 se dijo que estudiantes de La Cantuta son acusados por lo de Tarata, esperé la siguiente secuencia y nunca vino la noticia, entonces ¿quién filtraba esa información? Eso venía de Montesinos que sabía lo que había ocurrido hace tiempo, mucha de la información que los medios han repetido parte de esto: ocurre lo de Tarata, los de Cantuta son acusados por ello y luego ocurre la desaparición, pero no es así como ocurrieron las cosas. No hablan de una Cantuta intervenida militarmente, no hablan de 
una Cantuta con toque de queda, no hablan de que era imposible que alguien entrara o saliera y peor con carros. No hablan de una Cantuta donde la presencia militar era permanente, ese es el contexto de lo que vivimos el año 92. No hablan de un Poder Judicial que no existía, más de dos o tres jueces nombrados por Fujimori para desvirtuar cualquier tipo de investigación, y una época que no había congreso que es otro agravante para contextualizar que vivíamos en una dictadura. Distinto es El Comercio, no es que tenga un compromiso de construcción de memoria histórica, lo ha estado haciendo ahora porque está cambiando de imagen, ciento y tantos años como que El Comercio estuvo en la noticia y ha estado sacando extractos del juicio a Fujimori, de la salita del SIN, etc. Me parece bien porque son hechos de los que nadie habla y nadie se acuerda, pero sobre el compromiso de temas de derechos humanos no ha sido permanente, ha sido exactamente en casos donde ha tenido una mayor importancia o ha sido muy mediático, pero en general como noticia no lo hace. Yo debería marcar una diferencia, en todo caso, en el papel que ha cumplido La Republica y El Comercio. Cuando nosotros como familiares hacemos alguna actividad, un plantón, siempre le pedimos a alguien de La Republica que la cubran y alguna cosita va a sacar, aunque sea en la fotonoticia, pero alguna mención va a hacer; en otros medios ni sueñes que va a aparecer. Es claro que tienen una política distinta.

\section{¿Cree que la prensa ayudó a construir una memoria de lo que ocurrió? De ser así, ¿cuál es esa memoria?}

Sí, pero fue una memoria en que las FFAA nunca quisieron matar a ningún campesino, a ningún estudiante, se vieron forzadas por la declaratoria de guerra de Sendero Luminoso y no deberíamos culparlos de nada, o deberíamos perdonarnos y abrazarnos todos y un régimen principalmente pacificó al país, cosa que tampoco es cierto porque si no no tendríamos lo del VRAEM. Esa es la estrategia que es parte de esta memoria oficial donde todos los crímenes que ocurrieron en nuestro país son culpa del terrorismo, así de general. Cuando se habla de los muertos, casi nadie desde la memoria oficial, va a hablar de las víctimas de campesinos, estudiantes, caso Cantuta o lo que sea, hablan de los crímenes de terrorismo, que el único culpable en este país son los terroristas y no se habla de este otro lado de la memoria. Pero sí creo que en nuestro país no hay una memoria histórica es un proceso que nos cuesta construir, estamos siempre en pugnas de estas memorias, de esta memoria oficial que intenta acaparar todas las otras memorias y además que tiene mucha cabida en los medios de 
comunicación, casi aplasta a las otras memorias, a las memorias de las víctimas, las memorias de las comunidades que resistieron a Sendero pero que viven olvidadas por el Estado, de todo el nivel de impunidad que todavía se vive. Creo que estamos siempre en una pelea permanente. Yo no sé si eso es parte del proceso, hablamos de una historia muy reciente y hay que esperar un poco más para tener una memoria histórica. Estoy convencida de que tenemos la obligación de tener una memoria histórica, es parte de un hecho doloroso que nos ha tocado vivir como país, en el cual algunos hemos perdido más que otros pero que tiene que estar muy claro para todos no solamente por el peligro de un fujimorismo haciendo campaña sobre hechos que parecieran de otro mundo sino también de un Sendero reciclándose, MOVADEF, haciendo también campaña con unos jóvenes que dicen que era guerrilla, que los crímenes que se cometieron fueron el costo de una guerra pero que no era crímenes y también tergiversando la historia. Hay una obligación de construir esta memoria, pero no hay una política para hacerlo, no hay un Estado que la esté proponiendo, no hay un Estado preocupado por lo que va a pasar en este Lugar de la Memoria. Aquí como que nadie quiere hablar, en los textos escolares no lo ponen porque eso es apología, seguimos siendo cómplices de todo lo que ya pasó, de esas muertes y crímenes y lo que va a afianzándose es la indiferencia, no mirar, no escuchar, no involucrarse.

\section{¿Cuál es la principal carencia de los medios?}

Hay una falta de compromiso político con el país, más allá del grupo de poder que pudiera estar, poner anuncios o no, qué país estamos construyendo. Es obligación de todos, hay un nivel de responsabilidad también de los medios de comunicación y cuáles son los principios que van a regir para el nivel de información da. Muchos se llevan por el el tema del rating, la farándula, temas superficiales que no permitan que nosotros estemos pensando en los problemas país. Pero eso es tan banal que para mañana ya se olvidó y ahí apunta la responsabilidad educadora que debería tener un medio de comunicación para no solo el tema de la historia, sino de los derechos humanos, la no discriminación, la inclusión de las víctimas que son tan iguales como nosotros, tan peruanos como nosotros, con los mismos derechos y con el mismo valor de palabra que puede tener cualquiera. Esos principios tienen que estar claros en los medios de manera que lo que salga como noticia sea realmente lo que está pasando aquí y no sean hechos manipulados o de interés de esconderlos. Me imagino que debe ser difícil porque el medio igual es una empresa privada pero como lectora, como ciudadana, espero 
siempre más de ellos. Como la información fluye más rápido nos damos cuenta cuando algo se está ocultando o se está montando y entonces es más fácil descubrir la verdad, yo no sé si los medios están entendiendo el sentido de responsabilidad que tienen.

\section{¿Los periódicos son un lugar de memoria?}

Sí, no solamente porque tienen una edición diaria y es como un refrescar de memoria de todos los días. Es decir, no tienes que ir a la biblioteca, no tienes que comprarte un libro para recordar, el periódico lo tienes los días, puedes tenerlo en físico o en virtual pero la gente siempre va a buscarlos como fuente primaria de información, podrían ser espacios de memoria valiosos porque actualizarían esta información y la acercarían a la gente, sería una ocasión de recordar, no solo informando juicios, sino teniendo un espacio ya designado para algo que ha ocurrido en nuestro país.

\section{ANEXO 8: Entrevista a Martha Chávez}

Fecha: 18/06/2015

\section{La República y El Comercio dedicaron varias portadas a la sentencia a Fujimori, ¿a qué cree que se deba esto?}

Eso no es novedad para nosotros. Por lo menos en lo que atañe a mí, a mí también me metían presa todos los días cuando estaba procesada y salía en La República y en El Comercio mismo. Y claro siempre recuerdo en El Comercio decía violador de derechos humanos o asesino, ese fue un titular enorme. Decididamente es parte de la posición que ellos, desde el primer momento, tomaron de condenar a la persona y sobre todo de resaltar lo que podían haber dicho de otro modo: condenan, dictan sentencia, declaran culpable pero asesino, violador de derechos humanos o sea viene toda esa carga no ideológica, una carga emotiva, ¿no? En relación al que consideraron un adversario, una expresión de satisfacción de ver al adversario caído.

\section{La República se refirió como ex dictador o sátrapa a Alberto Fujimori, y El} Comercio aseguró que este secuestró y asesinó con alevosía, ¿cómo perciben esto?

Decididamente el propósito es de destruir, aniquilar al que consideran adversario pese a que tanto La República como El Comercio durante la época del presidente Fujimori en cuanto a temas económicos fueron los más beneficiados al punto que generaron otros medios, resultaron dueños de canales de televisión, que sé yo. Supuestamente podrían 
haber sido personas que estaban gratas en relación a los efectos positivos que para ellos tuvo el gobierno, la reestructuración y la reconstrucción del país. Pero más primaba quizás su desprecio porque de alguna manera también es un desprecio de carácter étnico, no hay que olvidar que al presidente Fujimori lo despreciaban por ser hijo de migrantes y ser hijo de japonés es peor, no es igual que ser hijo de migrante de Italia. Era la expresión de una carga guardada no solamente porque el presidente fue muy poco cortesano, no era de las personas que salía a tomar té con ciertos grupos de poder, en segundo lugar era un donnadie en el sentido que no era de elite social, era un profesional que se hizo de abajo y llegó a los más altos cargos tanto como rector, profesional y dirigente de todos los rectores pero de todas maneras era un outsider de cierta clase social y si encima era inmigrante peruano de primera generación con mayor razón. Era todo lo que ellos de alguna manera despreciaban, desde su torre de marfil.

\section{¿Los medios condenaron a Fujimori?}

Yo creo que influyeron mucho. A mí mientras estaba procesada: "hoy día condenan a Martha Chávez", no era "hoy día dictan sentencia", "hoy día ven caso de Martha Chávez", ya lo daban por hecho y esa es una presión muy efectiva. He conversado con jueces y dicen que han llegado a recibir de miembros del Tribunal Constitucional, "no Martha en algunos casos hay que soltar sino la prensa nos ataca”. Entonces hay un gran poder, a ti te pueden condenar o te pueden declarar inocente mediáticamente.

\section{Entonces, ¿fue un juicio mediático?}

También. Un juicio social, un juicio mediático, un juicio político, porque también tiene que ver mucho la carga social, "no eres de mi elite, no eres de mi entorno, no eres de mi grupo, entonces eres un extraño".

\section{La República otorgó un rol activo a los familiares de las víctimas en comparación}

\section{a los fujimoristas, ¿a qué cree que se deba?}

Ellos desde siempre. No hay que olvidar que La República, prácticamente pusieron en riesgo la vida de los rehenes y del comando Chavín de Huántar cuando revelaron la construcción de un túnel, pusieron en sobre aviso a los terroristas. Felizmente que los terroristas parece que se olvidaron o no creyeron que era así pero sí ha llegado a esos niveles. Ahora El Comercio siempre se cuida un poco pero decididamente con esos titulares ponía una carga de todo tipo. 


\section{¿Qué importancia tienen para ustedes los testimonios de los familiares?}

Yo digo como madre que es una posición muy cómoda y poco honesta porque creo que lo que debe hacer un padre o una madre es evitar que su hijo haga daños a otros, o sea vienen a llorar por la desgracia de sus hijos que jugaron con fuego, que no merecían esa muerte obviamente, pero no soy yo la que dice sino los periodistas como el propio Uceda, como Salcedo, que estas personas estaban, y está corroborado con los informes de la Dircote de esa época, vinculados a Sendero Luminoso, inclusive hay testimonios recientes en YouTube respecto de la hermana de uno de ellos, Gisela Ortiz, también vinculados. Por ese hecho no merecían la muerte obviamente, más aún si eran cuadros de tercer, cuarto nivel, si la cúpula está vivita y coleando pero decididamente ellos han logrado tener en La República porque, además, el fundador de La República, el padre del actual director, era de Acción Popular o socialista, o sea, era un empresario que se creía de izquierda, entonces se rodeó de estas personas y les dio cabida y estas personas pues tienen esta formación. Como a dé lugar deben bajarle la guardia y es una guerra de carácter psicológico también y propagandística, aprovechan de eso, pero el señor Mohme por ejemplo, nunca ha aclarado lo que Montesinos decía de él, que era un topo del SIN, y lo ha dicho en varias ocasiones. Y él ha admitido que iba al SIN, solo que dice que iba a conversar de temas del Estado, de la guerra con Ecuador, a él sí le creen y a otras personas que pueden haber ido incluso por razones de trabajo o pertenecer al gobierno han sido procesados, vilipendiados.

\section{¿Cómo percibe que no se dé tanta cabida a los fujimoristas en La República?}

Es una falta de respeto, los medios de prensa tienen en sus manos y deben ser analizados y evaluados por cómo respetan el derecho de los demás porque ellos manejan nuestra libertad indirectamente y si nos dan información defectuosa, información sesgada, información no cierta, los demás nos estaremos haciendo ideas, conceptos, opiniones y tomando decisiones injustas, impropias. Está en juego la libertad de las personas porque pueden ser direccionadas hacia decisiones que no tomarían $u$ opiniones que no tendrían si es que fueran debidamente informadas.

\section{El Comercio asegura, en una de sus portadas, "Fujimoristas quieren manipular la sentencia" y La República se refiere a ustedes como "beligerantes" contra el fallo, ¿cómo creen que son presentados en estos medios?}


Enseño en la universidad derecho constitucional y les digo a mis alumnos "no me crean a mí, vayan y lean los periódicos". Creo que el mejor modo que tienen los jóvenes para saber qué es lo que realmente vivimos en los años ochenta e inicios de los noventa en materia económica, de lucha contra el terrorismo, es ver los periódicos. O sea, agarrar de un mes de un año varios periódicos y así porque puede haber muchos libros tergiversados, incluso la misma Comisión de la Verdad fue una tergiversación institucionalizada de lo que vivió nuestro país. Si los jóvenes quieren conocer la historia o la escuchan de sus padres o abuelos porque ellos si pueden tener más o menos recuerdos de lo que significaba nuestra vida en esos tiempos, pero también ver los testimonios gráficos, lo que significó para nosotros el país como no teníamos un solo turista, como no teníamos un dólar de reserva, como gran parte de nuestro territorio estaba declarada en emergencia, como no teníamos cines, teníamos apagones, toques de queda, paros armados, las imágenes tan tremendas de militares secuestrados, empresarios y alcaldes acribillados, de jóvenes manipulados, bombas.

\section{Para usted, ¿los periódicos son un lugar de la memoria?}

Sí, a pesar de que su tergiversación porque de todas maneras los periódicos buscan presentar las noticias más truculentas, siempre apelan a eso. Entonces ahí puedes ver con algo de objetividad, por eso yo decía mira varios periódicos de una época, y sacas una línea.

\section{En ambos medios se recurren a antecedentes y a las víctimas para narrar La} Cantuta, ¿cómo cree que los medios relatan lo sucedido aquella noche? ¿cree que los medios aportan al conocimiento del caso?

Decididamente no la han contado bien porque ninguno de ellos se atrevió a decir ni a interesarse quienes eran estas personas, que reitero no es que eso va a significar que se los reconoce como terroristas y eso no va a significar que merezcan esa muerte. Había que también ocultar esa faceta perversa, malvada para hacerlos más víctimas aún, porque yo creo que cualquier persona entendería que esta gente se enroló al terrorismo, jugaron con fuego, causaron mucho dolor a mucha gente, yo creo que los militares que actuaron en el caso de La Cantuta les atribuyeron a ellos la responsabilidad de Tarata. Ahora, cierto o no, si fuera cierto, terrible. Por eso cuando me preguntabas el rol de los padres, ahora sí salen a llorar y lloran después de 20 años y por qué no lloran por los daños que sus hijos hicieron a otras madres, a otros hermanos, a otros hijos. Es muy 
cómodo para una familia pues dolerse de la tragedia de su hijo y cuando ese hijo pudo haber sido causante de la tragedia de otros. En ese contexto los periódicos quisieron santificar a esta gente, reitero nada justifica la muerte de ninguno más aun cuando los cabecillas están vivitos y coleando.

\section{¿Cree que la prensa ayudó a construir una memoria de lo que ocurrió? ¿cuál sería esa memoria?}

No, ellos por el odio hacia Fujimori se han olvidado y han querido ocultar que, en el gobierno de Alan García, de Belaunde, hubo más episodios de violaciones a los derechos humanos por las llamadas fuerzas del orden y más víctimas y número de casos. Han tornado toda la responsabilidad en el presidente Fujimori pero hay algo importante que siempre le digo a mis alumnos, de acuerdo al artículo 120 de la Constitución todos los actos de los presidentes son nulos si no tiene la refrendación ministerial y te dice además otro artículo, lo dice el 123, que los ministros son responsables individual y solidariamente de los delitos que cometa el presidente de la república. En el caso de La Cantuta y Barrios Altos al presidente lo condenan sin ninguna prueba de responsabilidad por autoría mediata por considéralo que hay una organización. ¿Qué ministro está condenado? Ninguno. Ese solo hecho demuestra que esa condena es inconstitucional, es impropia. No es que yo quiera que condenen a algún ministro, no quiero que condenen a nadie, pero eso solo te demuestra la inconstitucionalidad de esa sentencia.

\section{¿Podría asegurar que la memoria que ustedes defienden está aún con fuerza?}

Yo creo que sí. Pero la han opacado, la han tratado de opacar con otra memoria mucho más impactante, mucho más agresiva, que tiene muchos más recursos porque la otra memoria está en la memoria de la gente, en cambio la otra la construyen, la alimentan creando el Ojo que llora, creando el Lugar de la Memoria, un edificio, un armatoste, de tanto en tanto saliendo a recordar y rascando, si hay una memoria popular y hay una memoria institucional que no son las mismas, no coinciden.

\section{¿La prensa ha sido aliada de esa memoria que defienden?}

No, quizás algunos medios. La Razón, algunos medios que tienen abiertamente una posición así o algunos columnistas en la medida que los dejan, pero la mayoría no. 


\section{¿Cuál fue la principal carencia en la cobertura de este caso?}

Objetividad. De lo que se trata es de objetividad, por más que sea tu enemigo y es un poco apartarse de lo que se dice el ABC del periodismo, el periodismo debe tratar de presentar la noticia lo más neutro posible para opinión tienen su página editorial, sus columnas editoriales, la columna del director, yo creo que ellos convirtieron todo. Ese es el problema que veo en muchos medios, convierten todo, la noticia en parte de, en vehículo de su propia ideología y entonces terminan deformando, terminan omitiendo, acomodándolo, presentándolo a la medida de ellos

\section{ANEXO 9: Entrevista a Mario Mejía}

Fecha: 10 de julio del 2015

Tras revisar la cobertura a la sentencia a Alberto Fujimori, se encontró un menor despliegue en El Comercio respecto a La República, ¿a qué se debió?

En general, la cobertura de El Comercio fue amplia. El hecho de que a La República le interesara el tema de Fujimori y resaltarlo como sea, le haya dado aparentemente mayor cobertura, se debe a ese interés. Pero en El Comercio en ningún momento se trató de minimizar, todo lo contrario, siempre interesó el juicio dentro de nuestras notas, en política y actualidad, Fujimori era relevante. En muchas ocasiones pasó a ser el tema del día. Lo que pasa es que La República es un tabloide y tiene menos páginas, de pronto darle quizás la misma información al tema de un día ahí parezca grande porque tiene menos espacio. En La República se le han dado más páginas, pero El Comercio tiene ampliación de información de diversos sectores y grande. La difusión y la cobertura que se le daba al tema de Fujimori ha sido bien grande y se le dio bastante importancia de comienzo a fin, da esa apariencia, pero tiene que ver con el énfasis que le quiso dar La República al tema, pero es por su formato que parezca grande y en otros medios pueda parecer más pequeño. Creo que en todo caso El Comercio y La República fueron los medios que más difusión e importancia le dieron a este caso hasta el punto que yo cuando veía judiciales, las audiencias eran tres veces a la semana, iba a todas, no nos perdíamos ni una por más que supiéramos que ese día lo que se iba a ver no era tan importante pero siempre estuvimos cubriendo cosas que no iban a ser muy noticiosas como sí cuando fue Montesinos, por ejemplo. Había audiencias a las que no iba casi 
nadie, El Comercio y La República siempre ha estado dándole la importancia que tenía el tema.

\section{¿Fue un tema que marcó la agenda de El Comercio? ¿Por qué?}

Sí, claro. Fue algo a que se dijo desde un comienzo que se trataría con amplitud, obviamente con responsabilidad, no podía pasar a segundo plano, era de prioridad y siempre se le dio ese tratamiento. Había días sin mucha o muy repetitiva la información, los testigos que iban daban una declaración que no era, pero en otras oportunidades se veía responsabilidad del régimen de Fujimori y los testigos eran importantes, se les daba mucho más, en muchísimas ocasiones fue el tema del día de El Comercio, el tema del día es toda una página dedicada. Recuerdo que muchísimas veces tuve que hacer el tema del día que, para nosotros, los periodistas, es un poco cargado porque es ocuparte de toda una página solo con la información puntual, la trascendencia, lo que digan otras personas, análisis, era trabajar duro, pero estábamos contentos.

La mayoría fueron notas informativas, ¿a qué se debe esto? ¿Se privilegiaba la información y en menor medida la profundización? ¿Qué lugar ocupa el género interpretativo?

La inmediatez, había que dar cuenta de lo que estaba pasando y ahí objetivamente, puntualmente hacía que la bastante cantidad de información que se dio era un tema noticioso, de vez en cuando sí había en el lado editorial o se pedían columnas a gente para que analizaran, dieran una interpretación del tema. Por ejemplo, cuando Montesinos dijo hasta aquí no más voy a hablar pero al final la Sala dijo este testimonio no va a ser tenido en cuenta, por ejemplo ese caso específico se consultó con especialistas si la Sala había actuado bien, qué es lo que quiso hacer Montesinos, interpretar todo, se hizo una nota amplia con especialistas, abogados. Sí se trató de darle análisis, interpretación, pero lo que faltó fue hacer crónicas, quizás por una cuestión de falta de más personal, yo estaba concentrado en el tema, ahí hubiera sido interesante para dar un poco de variedad y otra perspectiva. Yo iba con el tema de dar la información de ese momento, de pronto si hubiese ido con otro periodista para que se diera de otro ángulo la audiencia. Posiblemente haya faltado eso para darle al lector todos los géneros que se pueda sobre el tema.

Se observó que entre sus fuentes también están fujimoristas, ¿cuál fue el papel que jugaron, entonces, los familiares de las víctimas? 
Tenían importancia. Había varios casos que yo consultaba con los familiares de La Cantuta, obviamente con los familiares de Fujimori, ellos siempre estaban presentes, ahí en las audiencias, siempre opinaban. Pero también con el otro lado, qué es lo que esperaba la familia, quizás no en gran sentido, porque era el día a día, por ejemplo, cuando iban los del grupo Colina y contaban las atrocidades que habían cometido siempre se conversaba con las víctimas de Barrios Altos, aunque más con La Cantuta, tenía más contacto con la gente de La Cantuta. Los llamaba, les pedía cuál era su opinión sobre las audiencias.

\section{¿Y la voz de fujimorista?}

Es una cuestión de practicidad. Se daba la audiencia, terminaba y había una especie de rueda de prensa donde hablaban las partes, el procurador, los fiscales nunca hablaban, el abogado de las víctimas, de la parte civil, y sobre todo el abogado de Fujimori, Nakasaki. Daban las declaraciones, se recogía eso y por la cuestión de que había que inmediatamente volver al diario, faltaba tiempo, con lo que tenías era con lo que trabajabas, y digamos en algunas cosas si se le consultaba pero en la mayor parte era con lo que tenías, era como suficiente, tenías lo que decían los abogados de ellos, lo que decía el abogado de Fujimori, lo que habías escuchado en la audiencia, como que casi no era tan necesario en todos los días conversar con ellos, salvo en algunos casos que sí quería saber la opinión de lo que había pasado, de las cosas que se habían dicho, por cuestión de espacio no había mucho, era ocupar la nota puntual de ese día, si se podía se ponía una reacción, una declaración de los familiares.

\section{Se percibe que la mayoría de fuentes fueron abogados, jueces y especialistas en la sentencia, ¿el diario está más relacionado a las fuentes judiciales?}

Claro, era nuestra relación más cercana con esta gente que era la que más hablaba, tenías la información de la audiencia y después inmediatamente todo ellos salían y daban su declaración, venia el abogado y hablaba obviamente lo que le interesaba, después venia el procurador o el abogado de la parte de las víctimas, a veces ellos no hablaban tampoco, se iban de frente y no querían. Obviamente Nakasaki sí quería ser escuchado, trataba de estar siempre ahí, por ese lado quizás parecía que se le daba más importancia al lado de Fujimori pero en todo caso era para equilibrar porque en las notas, la mayor parte era contra Fujimori. Casi todo apuntaba, bueno el juicio era contra Fujimori, para no ser anti, tratar de ver que dice su defensa entonces te digo que puede 
dar la sensación de que sí solamente se consultaba poco más a una parte y a la otra casi no se le tocaba, puede ser un poco la explicación. No era una cuestión de "no con ellos no, no queremos nada”. La posición del periódico siempre fue que se esclarezca esto, si se pensaba que había responsabilidad del régimen de Fujimori que se tradujo en toda la información que se produjo por más un año.

Lerner aseguraba que el periódico "no tenían ganas de reproducir las voces de la izquierda", ¿esto es cierto?

Salomón Lerner tiene cosas con El Comercio, ha tenido encontrones y no mira al diario con buenos ojos. No. No ha habido nada de eso, sino como te explicaba, era por esas condiciones que no se le daba, no se iba mucho a las fuentes de las víctimas, solo cuando nos parecía que sí era relevante.

En los textos informativos se observa que para dirigirse a Fujimoir se utiliza "ex mandatario" o "ex presidente, ¿hubo cuidado en el lenguaje para referirse a él? El Comercio trata de no adjetivizar. Se ponía "ex presidente", “el sentenciado", "el autor la matanza" no queríamos pone, bueno en los editoriales sí se le ponía todos los adjetivos, pero en la parte noticiosa se trataba de ser lo más objetivos y sin adjetivizar pero tampoco no era una intención de querer suavizarlo. Para no repetir las palabras se combinaban algunas, poco o casi nunca se usaba “dictador" pero sí “procesado". Recién con el juicio se iba a saber la culpabilidad, la responsabilidad. De ante mano no se puede decir.

\section{¿Y por qué en La República si sucedió esto?}

Sí, pero La República tiene ese sesgo más tirado a la izquierda, el periódico iba en esa línea, ellos sí eran una cuestión de que sí era culpable y que había que demostrar que era culpable. El diario decía que en el juicio se demuestre su autoría también asumiendo la posición y licencia, no podíamos de antemano decir si no había terminado el proceso. Intuíamos que sí, él era responsable y por eso se saludó al final el fallo que dio la Sala. El Comercio le pareció que fue un hecho histórico, en ningún momento se trató de proteger o de minimizar, o tratar de ocultar. Por lo menos a mí jamás me dijeron nada de eso, siempre tuve carta abierta para informar lo que se debía informar y nunca me

dijeron "esto no hay que ponerlo". Siempre toda la información que traje, todo lo que puse se respetó, no hubo ningún tipo de veto ni tratar de suavizar. Quizás mucha gente segura decía que La República pone esto, son diarios totalmente diferentes. Cada uno 
tiene sus intereses y la línea siempre ha sido antifujimorismo, El Comercio tampoco ha sido fujimorista, en sus editoriales siempre ha marcado su diferencia con el fujimorismo y con todas las cosas negativas que hizo. Pero muchos lectores o gente dicen no: "El Comercio sí ha tratado de minimizar", no ha sido así. Son los estilos que tienen cada diario y La República, bueno eso te lo dice la gente de izquierda, pero si le preguntas a uno de derecha te dice que La República está siempre parcializada, siempre sus notas le dan toda la importancia a los que están en contra, a los familiares, no ponen lo que dice Nakasaki y él siempre se quejaba porque La República nunca ponía nada de lo que decía. El Comercio ha tratado de ser lo más equilibrado posible, a algunos quizás no les gustaba eso. No hubo nada impuesto de decir no esto vamos a tratar de minimizarlo o de no atacar mucho a Fujimori, era solo lo que había en el día y presentarlo lo más equilibradamente posible, que el lector tenga la información amplia y completa de todos los lados y saque todas sus propias conclusiones. Esa es la razón por la que La República era sesgada. Lo que nosotros tratamos de presentar lo más neutral posible.

\section{La portada de El Comercio se refirió a que la inocencia de las víctimas de La} Cantuta, ¿cuál era la importancia de hacer énfasis en esto? ¿Puede dignificar la memoria de las víctimas?

Yo creo que justamente por eso mucha gente se sorprendió que se resaltara eso en la portada, podía estar en el interior en un parrafito y habías cumplido con dar la información, pero nos pareció que era una de las cosas trascendentales que se dio en el fallo, el reconocer a esas víctimas que por mucho tiempo se les dijo no, son terroristas, está bien que se les haya matado, así hayan sido terroristas no tenían derecho a haber recibido ese trato, haber sido asesinados y digamos era evidente de que no eran terroristas, había mucha gente inocente, víctima y aquí si fue una dirección de darle realce y que vaya de todas maneras en portada. Creemos que ese era uno de los puntos trascendentales, vitales, que había tenido el fallo, aparte de condenarlo y la dureza que tuvo la sentencia.

\section{¿Considera que existió un papel activo de El Comercio por construir una memoria de lo que sucedió con La Cantuta?}

Sí, pero hay tantos anticuerpos contra el diario ahí afuera, la gente no quiere ver. Por los anticuerpos que tiene El Comercio no se puede ver eso y bueno obviamente tampoco se resalta en el diario ese punto que hace que pueda ser que se interesa. Yo creo que sí 
tiene su importancia en esta empresa editora, pero no se da como en La República que sí, por la línea en la que está, siempre resalta más eso y la gente lo nota. Aquí en el diario no, pero si hay respeto porque va a ayudar a que este conflicto que hubo pueda de una vez cerrarse. Quizás no se note, pero si hay ese interés, quizás pequeño, de llegar a que esto termine bien.

\section{¿Cuál fue la principal carencia al cubrir un tema como La Cantuta?}

Quizás de pronto tener más equipo, ser un equipo mayor para ver más y analizar más el tema.

\section{ANEXO 10: Entrevista a Ángel Páez}

Fecha: $19 / 06 / 2015$

Tras revisar la cobertura a la sentencia a Alberto Fujimori, se encontró un mayor despliegue en La República respecto a El Comercio, ¿a qué se debió?

Nosotros en el diario como Unidad de Investigación decidimos profundizar en los procesos judiciales, o sea no solamente limitamos nuestro trabajo a hacer registro de las audiencias, de las declaraciones de los testigos, de la decisión del fiscal, de las decisiones de los magistrados, sino que buscamos aportar mayor información en todo momento y evidentemente lo hicimos.

\section{¿Fue un tema que marcó su agenda?}

Claro. Nosotros en los años noventa investigamos mucho el caso Fujimori y también el tema de la organización conocida como Destacamento Colina que fue protagonista de estos hechos que se le atribuye a Fujimori.

La mayoría fueron notas informativas, ¿a qué se debe?

Sí, claro son las notas informativas porque solo publicábamos investigaciones, reportajes de investigación, cada vez que teníamos algún ángulo novedoso del caso.

Sin embargo, se percibe una cantidad considerable de reportajes sobre la sentencia, ¿a qué se debe esto? ¿Qué lugar ocupa el género interpretativo?

Cuando hacemos investigación periodística usamos distintos géneros, crónica, reportaje, perfiles. Hay una variedad de géneros que hemos aplicado, pero como indiqué en un principio, eran dos formas de cobertura. Las noticias cotidianas, los 
incidentes, el proceso judicial, por un lado; y por otro los reportajes de investigación periodística, por ejemplo, uno de los aportes más importantes fue demostrar que los mismos del grupo Colina eran agentes en actividad del Servicio de Inteligencia del Ejército, es decir, era una unidad que pertenecía al cuerpo del ejército. Segundo, demostramos que eran financiados por el Ejército y en tercer lugar las planillas con las que se pagaban a estos agentes y además el tipo de transferencia del armamento del ejercito a estas personas, fue durante el proceso judicial y ¿por qué fue importante esta documentación? Durante todo el proceso el señor Fujimori y los testigos que presentó afirmaban que grupo Colina no existía.

\section{Entonces, ¿el día de la sentencia fue trascendental para el periódico?}

Más que para el periódico, para nuestro país porque nosotros como periodistas contribuimos a revelar, destapar, exponer información que va a ayudar a que las autoridades puedan tomar una decisión correcta. No lo hemos planteado como un éxito periodístico ni como una gran victoria del diario, sino en términos de que hemos cumplido con nuestro trabajo.

\section{Se solía utilizar "ex dictador" e incluso en alguna nota "sátrapa" para referirse a} Fujimori, ¿existía algún cuidado para referirse a algunos actores? ¿Por qué?

Tendríamos que ver el contexto, pero el término apropiado para este señor fue dictador porque el 5 de abril de 1992 instaló un régimen militar, cogobernó con la cúpula castrense que dominaba Vladimiro Montesinos en conjunción con Nicolás Hermoza Ríos. Para dar un ejemplo de una ley, un comandante general del ejército tiene que estar dos años, Fujimori y Montesinos hicieron la excepción y dejaron a Nicolás Hermoza Ríos por siete años con los resultados que conocemos: el señor es denunciado por corrupción, también por su vinculación con crímenes.

\section{¿Había alguna pauta en el medio para ello?}

No, acá no se decía hay que ponerle dictador a Fujimori o, es que depende del artículo que te refieres, pero no había esa indicación.

\section{¿Alguna intención?}

Seguramente es el reportero que ha usado ese término, pero no es porque acá se dice: "vamos a decirle tal cosa". No, no es así. 
En El Comercio se perciben columnas de opinión de Martha Chávez sobre la sentencia, ¿por qué en La República no sucede esto? ¿por qué no se le da voz a los fujimoristas?

Creo que sí ha habido, no en la misma cantidad porque hay que recordar que uno de los directivos miembros de los accionistas del diario El Comercio, Martha Meier, fue candidata del fujimorismo. Es obvio que ellos consideran darle más espacio a este tipo de personas que tienen esa línea, pero siempre se ha dado espacio para personas que ejercen la defensa de Fujimori. Recuerdo varias entrevistas al señor Nakasaki, a políticos o congresistas fujimoristas pero, como te digo, no en la dimensión que otros medios, pero sí lo hacíamos.

Entre sus fuentes, además de las judiciales, se percibe notoria presencia de los familiares de las víctimas y organismos de derechos humanos, ¿por qué? ¿a qué se debe esto? ¿Cuál es rol de los familiares? ¿Cuál es la importancia de ellos para el medio? ¿Cómo apoya esto para narrar lo ocurrido?

Claro, la línea del periódico consiste en dar espacio a los que son víctimas, de los que se abusa de sus derechos y a los que se les ha asesinado a un familiar con la finalidad de que se conozcan el punto de vista de ellos. Si tú recuerdas, durante el juicio había una parte de los familiares y otra parte de los fujimoristas, sus hijos. Si haces una pequeña revisión de todos los medios, en gran parte se le daba más espacio a Fujimori y su familia que a los familiares de las víctimas. Y bueno, la norma dice que el espacio siempre es preferente para las víctimas.

Cuando se estableció que las víctimas de La Cantuta no eran terroristas, La República le dedicó en la portada una tercera parte del espacio, ¿para qué? ¿Por qué? ¿Cuál era la importancia de hacer énfasis en esto?

Sí, porque hay un sector del país y hay un sector de los políticos que consideran que, entre comillas, el asesinato de los estudiantes y el profesor se justifica por el hecho de que eran terroristas. De hecho, en el proceso judicial algunos testigos señalaron eso, pero quedó acreditado por la presencia de varios testigos, entre ellos el ex jefe del grupo especial de inteligencia Benedicto Jiménez Baca y de otros más quienes aseguraban que no había ninguna evidencia de que estos señores eran terroristas.

¿Fue importante para ayudar a dignificar la memoria de las víctimas pese a que personajes como Martha Chávez continúan sosteniendo que eran terroristas? 
Bueno, no es precisamente un buen ejemplo de equilibrio, de transparencia, ella visitaba el SIN para recibir órdenes de Montesinos, pero está la resolución judicial que hay que respetarla así no te guste donde se dice que no eran terroristas.

\section{Entonces, ¿la cobertura ayudó a la memoria nacional?}

Fue un trabajo muy intenso y nosotros lo que hicimos fue practicar, aplicar los fundamentos de nuestro trabajo que consiste, fundamentalmente, en la búsqueda de la verdad y la búsqueda de la verdad significa conseguir fuentes de información, evidencia, documentos, testigos, confrontarlos, verificarlos y exponer los resultados, eso con un afán movilizado por el interés público, es decir, por el derecho de los ciudadanos a saber realmente lo que ocurrió.

\section{¿Cuál fue el rol de La República a construir memoria?}

Bueno, construir memoria entendiéndose como el acceso de las personas a conocer la verdad de los hechos, por supuesto.

\section{¿Y a narrar el pasado?}

Claro, sí, eso ha sido y los seguimos haciendo.

En cuanto a la ratificación, La República publicó primero esta, ¿a qué se debió esto?

No sé si se haya sido descuido o sea parte de la línea periodística de El Comercio. Como vuelvo a repetir, en ese período estaba esta persona que fue candidata al congreso por el partido fujimorista, lo que llama la atención porque el régimen de Fujimori persiguió, difamó, asesinó periodistas.

\section{¿Cuál fue la principal carencia al cubrir un tema como La Cantuta?}

Se hizo un gran despliegue, mucho esfuerzo para dar información al día, pero sí hubo algunos problemas de acceso, por ejemplo, a expedientes, etcétera. Pero, lo que sí notamos es que, vuelvo a repetir, siempre la mayor cobertura ha sido para la familia de Fujimori. Cada vez que hubo algún incidente judicial, casi todos los medios iban detrás de la señora Fujimori y de los familiares de las víctimas se olvidaban todos, como si fueran subalternos cuando en realidad son más importantes porque son víctimas. 


\section{ANEXO 11: Entrevista a Salomón Lerner Febres}

Fecha: 23/06/2015

\section{Se observó gran cobertura a la lectura de la sentencia a Fujimori en La República y El Comercio, ¿a qué cree que se deba esto?}

Habiéndose entablado un proceso judicial contra un antiguo presidente, se convierte en un juicio especial de modo paradigmático. Paradigmático, quiero ser claro, es en el sentido de que de algún modo al juzgar a Fujimori se tenía en cuenta su conducta, pero como presidente de algún modo simbolizaba un juicio también a aquellos elementos del estado que cometieron delitos en la época que se luchaba contra el terrorismo y que, pudiendo ser llevados a la justicia, no han podido porque simple y llanamente no ha habido información sobre esa gente. Cuando se ha tratado de investigar asesinatos y masacres ocurridas en el interior del país, evidentemente, lo primero que hay que decir que los grandes responsables de la tragedia del país son los terroristas: Sendero Luminoso. Pero eso no borra, no exonera de responsabilidad a aquellos miembros de las fuerzas del orden que por encargo del Estado cometieron, también equivocándose terriblemente en la estrategia, actos de terror: matando inocentes, torturando, violando mujeres. No son simples hechos de guerra, son crímenes que deben ser castigados. De algún modo, digo desde el punto de vista simbólico, el juicio a Fujimori es también un juicio a aquellos que no han podido ser llevados a los tribunales. Ahora, no significa que Fujimori sea el chivo expiatorio, sino que él mismo por su conducta fue juzgado en un proceso impecable, que es mostrado como ejemplo de la enseñanza del derecho aquí y en otros países. A él lo han condenado por crímenes de lesa humanidad y lo hicieron de acuerdo a una doctrina que a veces se la discute y por eso se dice que podría haber sido condenado injustamente, que es la teoría de los aparatos del poder donde se señala que tiene responsabilidad penal no solo aquel que mata si no aquel que ordena matar y eso dentro de una estructura, no interesa finalmente quien ejecute la orden, sino que se dé la orden. Eso es de algún modo aquello que ocurrió con Fujimori a través de Colina, que se encargaron de la matanza de los alumnos de Cantuta, era una especie de carta blanca a miembros del ejército para asesinar a aquellos que eran considerados cabecillas de Sendero. Entonces ese juicio estuvo muy razonado, muy bien llevado, con todas las posibilidades de defensa y fuera de ello hay que decir que Fujimori ha tenido otros juicios y ha sido condenado y él ya ha aceptado las condenas, es decir, hay muchos 
asuntos por los cuales se le ha juzgado y se le sigue juzgando. Esto de la autoría mediata, que es criticada por muchos, no es criticado cuando se trata del caso de Abimael Guzmán. No se puede decir que es válida la teoría de la autoría mediata para Guzmán y no lo es para Fujimori, ahí está probado en que ambos casos se han hecho juzgado.

\section{Entonces, ¿marcó la agenda de los medios? ¿Por qué?}

Sí, yo creo que sí. Nunca, que yo sepa, antes un presidente o que ha sido presidente de un país ha sido llevado a juicio y condenado. Que yo sepa en el Perú y es raro que en el extranjero suceda esto, lo han hecho en Argentina con Videla, pero ya era dictadores, aquí es un presidente constitucional que fue elegido la primera vez luego fue su autogolpe, pero la segunda vez también fue elegido y hubo una tercera vez. Es un juicio donde ha habido no solo la apreciación de hechos si no una interpretación de la ley y ha habido doctrina, es decir ha sido bastante completo y complejo.

En cuanto al lenguaje, se leyó que La República se refería a Fujimori como ex dictador e incluso sátrapa, ¿es relevante para contar la historia de violencia política?

Bueno, los periodistas utilizan una serie de términos, pero es claro para mí que en el caso de Fujimori hay pie para que se utilice eso. Cierto es que Fujimori a los dos años de haber sido elegido presidente la primera vez dio un autogolpe, disolvió el congreso, de acuerdo a la constitución que él desconoció, disolver el congreso hacía que él en ese mismo momento perdiera legitimidad como presidente solo que con apoyo de las fuerzas armadas, pero eso fue un atentado contra la democracia que él debía defender. Creo, además, que abusó del poder en el sentido de corromper a otro poder y eso se ve clarísimo con las compras de congresistas por parte de Montesinos para finalmente dictar leyes que le convenían a él más que al país. De hecho el enriquecimiento ilícito de él y de su entorno está absolutamente probado, las cuentas de Montesinos en el extranjero, yo se lo puedo decir porque estando en la CVR, la CVR trabajaba con los fondos recuperados de la corrupción, la plata que se había podido traer de Suiza.

\section{¿No es una falta de respeto y una muestra de desprecio como dice Martha Chávez?}

La señora Martha Chávez tiene una cierta historia que permite saber frente a qué tipo de persona nos estamos enfrentado. Ella señaló que Mariela Barreto se autotorturó y que los estudiantes de La Cantuta también se autoeliminaron. Aun cuando estos fueran 
terroristas, ¿el hecho de ser terroristas significa que se les pueda matar, en un país donde no hay pena de muerte y sin que haya juicio de por medio? Es una realidad, esa señora es abogada de esta universidad, es una vergüenza para la universidad y defender que un terrorista muerto está bien, que a un terrorista hay que matarlo, que un terrorista no puede ser de alguna manera también víctima. Hay terroristas a los cuales se los ha matado en el Frontón, Lurigancho, en Castro Castro, por más terroristas que sean con qué derecho se les quita la vida, son víctimas también, aunque eso le puede asquear a la señora Martha Chávez.

En cuanto a las víctimas, en La República se detectó una mayor participación de los familiares de las víctimas y Ángel Páez afirmaba que el lugar preferente lo han de tener las víctimas, ¿esto es así?

Claro y para la CVR también. La palabra primera la tienen las víctimas, decir qué es lo que vivieron, qué es lo que padecieron. No puede ser la historia de los victimarios o de gente neutra entre comillas porque aquí, en este asunto de 20 años de terrorismo, no hay gente neutra. La neutralidad es un absurdo, uno tiene que estar con quien es inocente, es víctima y el estado debía de haber defendido a todos los peruanos que estaban amenazados por el terrorismo y no usando el mismo terror.

\section{¿La voz de los familiares de las víctimas es relevante para narrar el pasado?}

Obviamente. Son ellos los que nos tienen que decir cómo habían sufrido, porque de otro modo no vamos a tomar conciencia de la realidad del país, del estado en el cual se encontraban y se siguen hallando una serie de zonas de nuestro país que están completamente ignoradas, donde no llega el Estado, donde no hay educación, donde no hay justicia ni nada de eso. Creo que las víctimas tienen por lo menos ese derecho. 


\section{ÍNDICE DE TABLAS}

TABLA 1. Entrevista a Gisela Ortiz y Martha Chávez ..................................................22

TABLA 2. Entrevista a Ángel Páez y Mario Mejía......................................................23 


\section{ÍNDICE DE FIGURAS}

FIGURA 1. Resumen total de publicaciones por períodos.......................................... 12

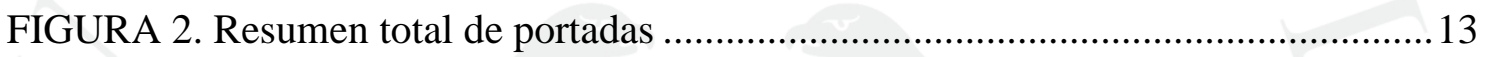

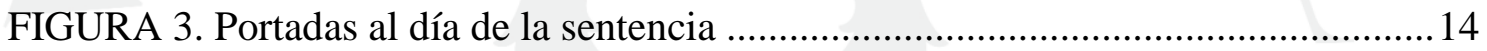

FIGURA 4. Portadas a la ratificación de la sentencia ..................................................... 14

FIGURA 5. Resumen total de géneros periodísticosFuente: Elaboración propia .......... 15

FIGURA 6. Géneros periodísticos antes del día de la lectura de la sentencia................ 16

FIGURA 7. Géneros periodísticos en la lectura de la sentencia..................................... 16

FIGURA 8. Géneros periodísticos en la ratificación de la sentencia ............................. 17

FIGURA 9. Portadas al día siguiente de la lectura de la sentencia ...............................20 